\title{
KEI en wat er (niet) verandert in het procesrecht in het civiele hoger beroep
}

\author{
$M r . d r s . F . J . P . L o c k^{*}$
}

\begin{abstract}
1 Inleiding
Over het programma Kwaliteit en Innovatie rechtspraak (KEI) en de daarmee samenhangende wetsvoorstellen tot wijziging van het Wetboek van Burgerlijke Rechtsvordering (Rv) is al op diverse plaatsen, ook in dit tijdschrift, geschreven. ${ }^{1} \mathrm{Het}$ accent heeft daarbij vooral gelegen op de wijzigingen voor de procedure in eerste aanleg. Aan de wijzigingen die deze wetsvoorstellen meebrengen voor de procedure in hoger beroep is minder aandacht besteed. Deze bijdrage beoogt in kaart te brengen wat er met de invoering van het gewijzigde $\mathrm{Rv}$ al dan niet in het appelprocesrecht verandert.
\end{abstract}

Met KEI beoogt de wetgever vereenvoudiging, versnelling en digitalisering van - onder meer - de civiele procedure te bewerkstelligen. ${ }^{2}$ Het programma valt uiteen in een deel dat is gericht op het procesrecht (KEI-wetgeving) en een deel dat is gericht op de digitalisering van de procedure (KEI-rechtspraak). Deze bijdrage richt de blik vooral op de KEI-wetgeving en de daarin voorziene wijzigingen in het Rv. Wetsvoorstel 34059 bevat daartoe voorstellen tot wijziging voor de procedure in eerste aanleg. Wetsvoorstel 34138 bevat wijzigingsvoorstellen voor de procedure in hoger beroep en cassatie. Wetsvoorstel 34212 is een voorstel voor een invoeringswet. ${ }^{3}$ Met deze wetsvoorstellen streeft de wetgever ook voor

Mr. drs. F.J.P. Lock is senior-raadsheer in gerechtshof Arnhem-Leeuwarden en tevens als onderzoeker verbonden aan de Radboud Universiteit Nijmegen.

1. Zie o.a. J. Ekelmans, Het wetsvoorstel voor de civiele rechtsgang in eerste aanleg: met het hoofd en hard?, NTBR 2014, afl. 8, p. 48-63; J.L.R.A. Huydecoper, Veranderingen in het procesrecht - nieuw, verbeterd!, NJB 2014/1274, p. 1750-1754; H.F.M. Hofhuis, Vernieuwing van het civiele proces, Trema 2015, p. 10-18; A.I.M. van Mierlo \& P.J.J. Vonk, Vereenvoudiging en digitalisering van het procesrecht; procederen in nieuwe jas na KEI, WPNR 2015/7065, p. 511 e.v.; K. Teuben \& K.J.O. Jansen, Het Wetsvoorstel vereenvoudiging en digitalisering procesrecht: kanttekeningen vanuit de procespraktijk, TCR 2015, afl. 2, p. 3-12; J.D.A. den Tonkelaar, De regisserende zaaksrechter: de regierol van de rechter volgens KEI, TCR 2015, afl. 4, p. 105-113; C.J.M. Klaassen, De civiele procedure volgens 'KEI', RMThemis 2016, afl. 2, p. 74-84.

2. De wetgevingsoperatie heeft ook betrekking op het bestuursrecht; dat onderdeel laat ik onbesproken.

3. Op 12 juli 2016 heeft de Eerste Kamer met de wetsvoorstellen ingestemd. Naar verwachting treedt de KEI-wetgeving (op zijn vroegst) per 1 februari 2017 in werking en die wordt dan gefaseerd ingevoerd (zie <www.rechtspraak.nl/SiteCollectionDocuments/Tijdlijn-KEI.pdf>).

De geconsolideerde tekst van de wetsvoorstellen, met een inleiding van De Groot en Ernste, is reeds in gedrukte vorm beschikbaar: G. de Groot \& P.E. Ernste, Tekstuitgave KEI. Geconsolideerde wetteksten Wetboek van Burgerlijke Rechtsvordering, Wet griffierechten burgerlijke zaken en Rijkswet cassatierechtspraak, Den Haag: Boom juridisch 2016. het hoger beroep naar vereenvoudiging en versnelling van de procedure. Die zouden moeten plaatsvinden door de invoering van een uniforme procedure, waarin de rechter middelen heeft om een vlot verloop van de procedure te bewerkstelligen en waarin wettelijke termijnen gelden voor het verrichten van proceshandelingen en het doen van uitspraak door de rechter.

\subsection{Wat niet verandert}

Aan de hoofdlijnen van het appelprocesrecht wordt niet getornd. Zo beogen de wetsvoorstellen geen wijzigingen aan te brengen in de devolutieve werking van het hoger beroep, het grievenstelsel en de tweeconclusieregel. Deze bijzondere, vooral in de rechtspraak ontwikkelde, regels van appelprocesrecht heeft de wetgever ongemoeid willen laten. De minister heeft zich wel gerealiseerd dat de roep om het grievenstelsel en de devolutieve werking te herzien aanwezig is. Tegelijkertijd heeft hij geconstateerd dat de discussie hoe die aanpassing zou moeten plaatsvinden en moeten worden uitgewerkt nog niet is uitgekristalliseerd. Een wijziging op dit punt zou zeer ingrijpende gevolgen kunnen hebben voor de wijze van procederen in hoger beroep. Dat gaat, naar de mening van de minister, de doelstellingen van het wetsvoorstel te buiten. ${ }^{4}$

\subsection{Wat wel verandert}

Volgens de memorie van toelichting leiden de wetsvoorstellen tot vijf wezenlijke veranderingen: ${ }^{5}$

a. vermindering van de verschillen tussen dagvaardingsprocedure en verzoekschriftprocedure, onder meer door een uniforme procesinleiding;

b. afschaffing van de verplichting tot het betekenen bij exploot van de huidige dagvaarding;

c. invoering van wettelijke termijnen voor het verrichten van proceshandelingen en het doen van uitspraak;

d. meer regie door de rechter;

e. digitalisering van de procedure.

Deze veranderingen worden grotendeels ook in hoger beroep doorgevoerd, tenzij de aard van de procedure in hoger beroep zich daartegen verzet.

De digitalisering zal er - kort gezegd - in bestaan dat de procedure in hoger beroep digitaal kan worden gestart via een webportaal en dat de processtukken vervolgens digitaal kunnen -

4. Kamerstukken II $2014 / 15,34138,3$, p. 8 .

5. Kamerstukken II 2014/15, 34059, 3, p. 5-8. 
en in de meeste gevallen: moeten - worden ingediend. ${ }^{6} \mathrm{KEI}$ Rechtspraak ontwikkelt het webportaal voor de rechtbanken en de hoven en dit zal via een gezamenlijke inlogpagina (die waarschijnlijk MijnRechtspraak.nl gaat heten) bereikbaar zijn. Partijen kunnen via het digitale systeem stukken indienen of stukken ophalen die hun in dat systeem ter beschikking worden gesteld. Via het portaal (en een systeemkoppeling) kunnen ook in hoger beroep processtukken worden ingediend, kunnen de gerechten mededelingen over de voortgang van de procedure plaatsen en kunnen partijen inzage krijgen in hun digitale dossier. ${ }^{7}$

Dat digitalisering als laatste van de vijf wezenlijke veranderingen die met KEI worden beoogd, wordt genoemd, is overigens opmerkelijk. ${ }^{8}$ Digitalisering lijkt het hoofddoel, aan het realiseren waarvan de andere doelstellingen dienstbaar zijn. ${ }^{9}$ Dat is ook de reden waarom veel suggesties om de wetswijziging aan te grijpen om nog meer fundamentele wijzigingen door te voeren niet zijn overgenomen. ${ }^{10}$ Hoewel digitalisering een belangrijke, en misschien wel de belangrijkste, doelstelling van het KEI-project is, zal ik deze toch niet apart bespreken. Deze doelstelling werkt namelijk door in de andere doelstellingen. Waar deze digitaliseringsdoelstelling heeft geleid tot wijzigingen in Rv komt dat bij de bespreking van de andere onderwerpen vanzelf aan de orde. De technische aspecten die samenhangen met het KEI-deel dat is gericht op procesvernieuwing en digitalisering (KEI Rechtspraak) laat ik onbesproken. Daarvoor verwijs ik naar hetgeen daarover reeds door anderen is geschreven. ${ }^{11}$

De overige door de wetgever benoemde wezenlijke veranderingen $(\mathrm{a} \mathrm{t} / \mathrm{m} \mathrm{d})$ vormen de structuur aan de hand waarvan ik zal beschrijven welke concrete veranderingen KEI voor de procedure in hoger beroep met zich brengt. Daarbij zal ik de veranderingen of juist het uitblijven daarvan van context en commentaar proberen te voorzien. ${ }^{12}$ Als ik wetsartikelen noem, bedoel ik de wetsartikelen van het nieuwe Rv. Als ik op de thans vigerende wetgeving doel, zal dat uit het verband wel

6. Zie daarover verder par. 3.1.

7. Kamerstukken II 2014/15, 34138, 3, p. 16.

8. Klaassen 2016, p. 78 wees daar ook al op.

9. Kamerstukken II 2014/15, 34059, 3, p. 7.

10. Zie o.a. Kamerstukken II 2014/15, 34059, 3, p. 61 aangaande het bewijsrecht, Kamerstukken II 2014/15, 34138, 3, p. 8 aangaande het appelprocesrecht en Kamerstukken II 2014/15, 34138, 3, p. 19 aangaande het procesrecht in cassatie.

11. Zie het KEI-themanummer RMThemis 2016, afl. 2, meer in het bijzonder de bijdragen daarin van E. Bauw, KEI, een gamechanger voor de civiele en bestuursrechtspraak?, en C.M. Aarde \& J.E.J. Prins, Digitalisering binnen de rechtspraak: van KEI naar Big Data. Zie hierover ook H.W. Wefers Bettink, Digitalisering van de civiele procedure: gevolgen voor de procespraktijk, TCR 2015, afl. 1, p. 1-6.

12. Bij Boom juridisch is een uitgave in ontwikkeling waarin de KEI-wetgeving zal worden voorzien van de belangrijke passages uit de wetsgeschiedenis en waarbij de wijzigingen artikelsgewijs van commentaar zullen worden voorzien. Ik hoop aan die uitgave ook een bijdrage te leveren. Hetgeen in dit artikel wordt beschreven zal naar verwachting voor een deel ook in die uitgave een plaats krijgen. blijken of zal ik dat er uitdrukkelijk bij vermelden door gebruik van het woord 'huidig'.

\section{Uniformering van de procedure; procesinleiding}

\subsection{Vorm en inhoud}

De dagvaarding in hoger beroep in dagvaardingszaken wordt vervangen door de procesinleiding in hoger beroep (art. 343 lid 1). De procesinleiding gaat ook gelden als toegang tot het hoger beroep in geval van verzoekschriftprocedures (art. 359). Met deze uniforme procesinleiding, waarbij alle civielrechtelijke procedures op dezelfde wijze starten, staat de wetgever voor ogen dat de toegang tot de rechter eenvoudiger wordt. ${ }^{13}$ De term voor het inleidend processtuk (procesinleiding) is gelijk aan de term voor het inleidend processtuk in eerste aanleg. Dat is een uitdrukkelijke keuze, met name uit wetstechnisch oogpunt. ${ }^{14}$ Waar nodig kan de term worden onderscheiden als 'procesinleiding in hoger beroep'. Met de introductie van de uniforme procesinleiding vervallen dus de termen 'dagvaarding' (of: 'appeldagvaarding'), 'verzoekschrift' en 'beroepschrift'. In het kielzog daarvan worden dagvaardingszaken voortaan 'vorderingsprocedures' genoemd en verzoekschriftprocedures gaan 'verzoekprocedures' heten. De conclusie van eis, die in hoger beroep nog bestond, behoort daarmee ook tot het verleden.

De procesinleiding in hoger beroep moet in beginsel aan dezelfde vereisten voldoen als de procesinleiding in eerste aanleg. ${ }^{15}$ Uitzonderingen daarop (art. 343 lid 4) zijn de zogenoemde substantiëringsplicht en bewijsaandraagplicht (art. 30a lid 3 onder $f$ en $g$ ).

Ook de vorm waarin de procesinleiding moet worden uitgebracht, zal in beginsel dezelfde zijn als die in eerste aanleg (zie daarover ook par. 3.1).

\subsection{Gecombineerde procedure}

Ingevolge art. 343 lid 2 kan met één procesinleiding hoger beroep worden ingesteld van een uitspraak waarbij zowel is beslist op een verzoek als op een vordering. In dat geval zijn de bepalingen van de vorderingsprocedure van toepassing (art. $30 \mathrm{~b}$ ). Tussen de vordering en het verzoek moet wel voldoende samenhang bestaan en de Nederlandse rechter moet ten aanzien van de behandeling van en beslissing op zowel de vordering als het verzoek rechtsmacht toekomen. Of gezamenlijke behandeling zich verdraagt met de goede procesorde, of dat de zaak gesplitst moet worden, wordt door de rechter in hoger beroep opnieuw beoordeeld. ${ }^{16}$

13. Kamerstukken II $2014 / 15,34138,3$, p. 5 .

14. Ibid.

15. Dat behandel ik hier verder niet; ik verwijs daarvoor naar de beschrijving van de procesinleiding in de basisprocedure door Van Mierlo \& Vonk 2015, p. 511 e.v.

16. Kamerstukken II 2014/15, 34059, 3, p. 19 en Kamerstukken II 2014/15, 34138, 3, p. 5 en 14. 
Voor de mogelijkheid van het instellen van hoger beroep gelden voor vordering en verzoek de eigen regels van de vorderings- respectievelijk de verzoekprocedure. Wanneer tegen een uitspraak op een vordering of een verzoek geen hoger beroep (of cassatie) openstaat, is het gevolg van een gecombineerde indiening niet dat daardoor alsnog hoger beroep mogelijk wordt, tegelijk met het verzoek of de vordering waartegen wel hoger beroep openstaat. Ook als er in bijzondere bepalingen voor een vorderings- of verzoekprocedure een afwijkende termijn voor het instellen van hoger beroep staat, is deze (kortere) termijn leidend voor het instellen van het gehele, gecombineerde, hoger beroep. ${ }^{17}$ Het verdient daarom aanbeveling dat de rechter die uitspraak doet in een procedure waarin een vordering en een verzoek zijn gecombineerd per onderdeel aangeeft welk deel van de uitspraak betrekking heeft op een vordering (en derhalve kwalificeert als vonnis) en welk deel van de uitspraak betrekking heeft op een verzoek (en derhalve kwalificeert als beschikking). Daarbij teken ik overigens nog wel aan dat deze kwalificatie naar huidig recht de appelrechter niet bindt. Die zal zelf moeten beoordelen in hoeverre sprake is van een vonnis of een beschikking (met andere woorden: of sprake is van een beslissing op een verzoek of op een vordering); de werkelijke aard van de beslissing is doorslaggevend. ${ }^{18}$ De appellabiliteit van de beslissing op de vordering respectievelijk het verzoek vereist nog wel een afzonderlijke beoordeling waar het de financiële appelgrens betreft (zie par. 2.4).

Overigens is het volgens jurisprudentie van de Hoge Raad al mogelijk om bij één dagvaarding hoger beroep in te stellen tegen uitspraken die op dezelfde dag door dezelfde rechter tussen dezelfde partijen zijn gewezen. Maar het moet daarbij dan wel gaan om zaken die voldoende met elkaar samenhangen om gezamenlijk door dezelfde rechter te worden beslist. ${ }^{19}$ Deze rechtspraak ziet (dus) niet op gevallen waarin zowel op een vordering als op een verzoek werd beslist. Tegen die uitspraken moest immers op andere wijze hoger beroep worden ingesteld (appeldagvaarding respectievelijk beroepschrift). In zoverre is het tweede lid van art. 343 dus meer dan een codificatie van deze rechtspraak. Die rechtspraak blijft mogelijk nog wel van belang voor de gevallen waarin in samenhangende zaken niet bij één maar bij verschillende uitspraken op een verzoek en een vordering is beslist. Het verschil in procesinleiding bestaat niet meer nadat digitaal procederen voor beide procedures in werking is getreden..$^{20}$ De wet biedt thans uitdrukkelijk de mogelijkheid om vorderingen en verzoeken tegelijk te behandelen en te beslissen. Gelet daarop ligt het voor de hand dat de rechter in een dergelijk geval eerder geneigd zal zijn om het hoger beroep dat bij één procesinleiding tegen deze uit-

17. Kamerstukken II 2014/15, 34059, 3, p. 18 en 61, alsmede 4, p. 7-8.

18. Zie o.a. HR 6 november 1964, ECLI:NL:HR:1964:AB3963, HR 17 november 1966, ECLI:NL:HR:1966:AB5122 en HR 19 maart 1982, ECLI:NL:HR:1982:AG4346.

19. HR 21 juni 2013, ECLI:NL:HR:2013:BZ8317, NJ 2014/248 m.nt. Snijders.

20. KEI zal gefaseerd in werking treden, waarbij het ernaar uitziet dat de digitalisering van de vorderings- en verzoekprocedures niet gelijk op zal lopen. spraken wordt ingesteld, ontvankelijk te achten. Ik zou menen dat de rechter ook in een dergelijk geval de vrijheid zou moeten hebben om het bij één procesinleiding ingestelde hoger beroep overeenkomstig de regels van art. $30 \mathrm{~b}$ te behandelen.

\subsection{Gronden van het hoger beroep}

De huidige praktijk dat de appeldagvaarding in vorderingszaken nog niet de gronden van het hoger beroep behoeft te bevatten, wordt gehandhaafd. Dat volgt uit art. 343 lid 3. Volstaan mag worden met een 'kale' procesinleiding. De gronden van het hoger beroep (in de huidige praktijk 'grieven' genoemd $\left.^{21}\right)$ mogen in een later processtuk worden aangevoerd.

De praktijk dat in de verzoekprocedure in beginsel wel direct de gronden van het hoger beroep moeten worden opgenomen, is eveneens gehandhaafd (art. 359 jo. art. 30a). Van uniformering van de procesinleiding in vorderings- en verzoekprocedures is in zoverre dus geen sprake.

Er is wel overwogen om ook in vorderingszaken te bepalen dat de gronden onmiddellijk in de procesinleiding moeten worden opgenomen. Daarmee zou hoger beroep in vorderingszaken niet langer afwijken van hetgeen geldt in eerste aanleg, in verzoekprocedures en in cassatie. Bij de hoven bestaat de praktijk om in de periode tussen het aanbrengen van de zaak en het indienen van de memorie van grieven in daartoe geselecteerde zaken een zogenoemde comparitie na aanbrengen te houden. Deze comparitie is vooral bedoeld om voordat partijen zich (verder) ingraven in hun standpunten en reeds kosten maken in hoger beroep te bezien of de zaak zich alsnog leent voor een minnelijke regeling. ${ }^{22}$ De verplichting om de gronden van het hoger beroep al in het procesinleidend stuk op te nemen zou met deze doelstelling botsen. De wens om de praktijk van de comparitie na aanbrengen te kunnen handhaven heeft de wetgever daarom ervan doen afzien om ook in vorderingszaken te verplichten tot het opnemen van de gronden van het hoger beroep in de procesinleiding. ${ }^{23}$

Indien sprake is van een gecombineerd hoger beroep in zowel een verzoek- als vorderingsprocedure lift het hoger beroep tegen de beslissing op het verzoek mee met de mogelijkheid om in het hoger beroep tegen de beslissing in de vorderingsprocedure de gronden later aan te voeren. Bestaan er echter ingevolge bijzondere wettelijke bepalingen voor bepaalde verzoekprocedures afwijkende voorschriften (bijvoorbeeld in het

21. De term grieven dekt eigenlijk niet goed de lading (zie hierover o.a. de instructieve noot van Lewin onder HR 27 juni 2014, ECLI:NL:HR: 2014:1557, JBPr 2014/39). De wetswijziging lijkt me een goede aanleiding om voortaan zowel in vorderings- als in verzoekprocedures over 'gronden' te spreken. Daardoor wordt de terminologie meer uniform. Dat heeft de wetgever ook voor ogen gehad (Kamerstukken II 2014/15, $34138, .3$, p. 16).

22. Zie hierover W.L. Valk \& C.G. ter Veer, De comparitie na aanbrengen in hoger beroep, NJB 2005, p. 1985-1987; F. Askvig, Comparitie voor de memorie van grieven, PP 2006, p. 218-221; R. Dozy, De comparitie voor grieven, TCR 2012, afl. 2, p. 43-48.

23. Kamerstukken II 2014/15, 34138, 3, p. 6-7 en 27. 
familierecht), dan hebben die voorrang boven deze algemene regel. ${ }^{24}$

\subsection{Financiële appelgrens}

Van diverse kanten heeft de roep geklonken om de appelgrens van $€ 1750$ te verhogen. ${ }^{25}$ Desondanks heeft de wetgever daaraan (nog) geen gehoor willen geven. Een dergelijke aanpassing zou buiten het bestek van het programma KEI vallen, aangezien dit niet noodzakelijk is voor het behalen van de doelen van dit programma. ${ }^{26}$ Inhoudelijk blijft art. 332 over de financiële appelgrens in vorderingszaken dus ongewijzigd.

De terminologie moest wel worden aangepast. Ook in hoger beroep wordt immers niet langer over een 'dagvaarding' als het procesinleidend stuk gesproken, maar is gekozen voor de term 'procesinleiding'. De procedure is aanhangig vanaf het moment dat de vordering door middel van een (digitale) procesinleiding bij de rechtspraak is ingediend (art. 30a lid 1). Het peilmoment voor de bij de bepaling van de appelgrens in acht te nemen rente over de gevorderde hoofdsom is daardoor niet langer de dag van dagvaarding maar de dag van het indienen van de procesinleiding (art. 30a). Ook in art. 332 lid 3 is de terminologie aangepast. Overeenkomstig de bepalingen voor de procedure in eerste aanleg wordt niet langer gesproken over een vordering in conventie en een vordering in reconventie, maar over 'vordering' en 'tegenvordering'. Voor de toepassing van de appelgrens makt dit verder geen verschil.

In geval van objectieve cumulatie ${ }^{27}$ worden voor het antwoord op de vraag of de appelgrens is bereikt de waardes van de vorderingen bij elkaar opgeteld (art. 332 lid 2).$^{28}$ Deze regel geldt evenwel niet ingeval in een gecombineerde procesinleiding zowel een vordering als een verzoek wordt ingediend (zie par. 2.2). Indien gelijktijdig uitspraak is gedaan op een vordering en een verzoek, kan daarvan gelijktijdig hoger beroep worden ingesteld (art. 343 lid 2) en gelden in beginsel de bepalingen van de vorderingsprocedure (art. 30b lid 2). Maar dat geldt niet voor het instellen van hoger beroep zelf (art. 30b lid 3). Voor de mogelijkheid van het instellen van hoger beroep blijven voor verzoek en vordering de eigen regels van de vorde-

24. Kamerstukken II 2014/15, 34138, 3, p. 14.

25. Zie o.a. Agenda voor de appelrechtspraak 2020, Den Haag: Sdu Uitgevers 2013, p. 15, aanbeveling 3: 'De financiële appelgrens wordt angepast aan de eisen van de tijd en gaat omhoog naar $€ 5.000$, uitgezonderd die zaken waarin verlof tot hoger beroep wordt verleend', G. van Rijssen, Gedachten over Innoverende Hoven, in: A. Hol \& J. Verburg (red.), Innoverende hoven, Den Haag: Boom Juridische uitgevers 2014, p. 178, alsook B.T.M. van der Wiel, Toegang tot hoger beroep: de poort moet open blijven, in dezelfde uitgave, p. 186. Zie ook, zij het aarzelend, A. Hammerstein, Toegang tot en omvang van het hoger beroep, in: P.H.P.H.M.C. van Kempen e.a. (red.), Hoger beroep, renovatie en innovatie, Deventer: Kluwer 2014, p. 71.

26. Kamerstukken II 2014/15, 34138, 3, p. 24.

27. Verschillende vorderingen die bij hetzelfde processtuk worden ingesteld.

28. Waarbij geldt dat ook indien de rechter over het gevorderde beslist in meer (deel)vonnissen, voor de appellabiliteit van elk van de (deel)vonnissen het totale beloop of de totale waarde van het gevorderde waarover de rechter had te beslissen in aanmerking dient te worden genomen: HR 18 april 2014, ECLI:NL:HR:2014:946. rings- respectievelijk de verzoekprocedure gelden. Wanneer tegen een uitspraak op een vordering of een verzoek geen hoger beroep (of cassatie) openstaat, is het gevolg van een gecombineerde indiening niet dat daardoor alsnog hoger beroep mogelijk wordt, tegelijk met het verzoek of de vordering waartegen wel hoger beroep openstaat. Voor de verzoekprocedure geldt geen financiële appelgrens, voor een vorderingsprocedure wel. Indien sprake is van een gecombineerde procesinleiding, waarin zowel sprake is van een vordering als van een verzoek, zal de vraag of de beslissing op het verzoek appellabel is, niet afhankelijk zijn van de hoogte van de waarde van de vordering. En bij een gecombineerde procedure is de eventuele waarde van het verzoek niet van invloed op de vraag of de appelgrens is bereikt. Indien sprake is van een gecombineerde procesinleiding terwijl de waarde van de vordering waarover de rechter had te beslissen beneden de appelgrens ligt, zal van de beslissing op de vordering geen hoger beroep openstaan, ongeacht wat het financiële belang bij het verzoek is. Kortom: de appellabiliteit van vordering en verzoek dient afzonderlijk te worden beoordeeld. Dat op zowel vordering als verzoek gelijktijdig uitspraak is gedaan en dat daarvan gelijktijdig hoger beroep wordt ingesteld, maakt dit niet anders.

\subsection{Verstek en verzet}

Tegen veroordelingen bij verstek staat geen hoger beroep open (art. 335); daarvan moet de gedaagde (die verweerder gaat heten), wil hij tegen de veroordeling opkomen, verzet instellen. Dat verandert niet.

Het kiezen van het verkeerde rechtsmiddel kan, indien de verzettermijn inmiddels is verstreken, in procesrechtelijk opzicht fataal zijn. Er bestaat geen bepaling ingevolge welke de rechter een hoger beroep dat is ingesteld door een bij verstek veroordeelde partij kan converteren en de zaak kan verwijzen naar de rechtbank teneinde die als een verzetzaak te beoordelen. Evenmin kan de rechtbank een verzet dat eigenlijk een hoger beroep had moeten zijn, verwijzen naar het hof. Een wisselbepaling zoals die bestaat voor het geval een partij de dagvaardingsprocedure heeft gevolgd terwijl het de verzoekschriftprocedure had moeten zijn of vice versa (art. $69 \mathrm{Rv}),{ }^{29}$ bestaat niet voor het geval iemand hoger beroep instelt in plaats van verzet of andersom. ${ }^{30}$ Ook een voorziening zoals die van art. 340 (nieuwe termijn indien beroep in cassatie is ingesteld in plaats van hoger beroep, zie ook par. 2.6) bestaat niet voor het geval verzet is ingesteld in plaats van hoger beroep, of andersom. De gevolgen daarvan kunnen zich met name laten gevoelen in het geval art. 140 lid 3 van toepassing is. Ingevolge art. 140 lid 3 wordt, indien sprake is van meer verweerders en indien ten minste één van hen in het geding is verschenen, tussen alle partijen één vonnis gewezen dat als een vonnis op tegenspraak

29. Waar zowel vorderingen als verzoeken bij dezelfde procesinleiding worden ingesteld of gedaan, zal die wisselbepaling aan belang inboeten, hoewel nog altijd geldt dat voor het instellen van een vordering of het indienen van een verzoek in sommige opzichten eigen regels gelden; de wisselbepaling zal daarom wel in aangepaste vorm blijven bestaan.

30. HR 17 januari 1992, ECLI:NL:HR:1992:ZC0479, NJ 1992/263. 
wordt beschouwd. Tegen dat vonnis staat geen verzet open, maar alleen hoger beroep, ook voor de niet-verschenen verweerder(s). Dat betekent dat ook voor de niet-verschenen verweerder(s) de reguliere beroepstermijn geldt. ${ }^{31} \mathrm{Ik}$ kan mij goed voorstellen dat soms onduidelijk is of zich de situatie van art. 140 lid 3 voordoet. ${ }^{32}$ Natuurlijk doet een advocaat er dan verstandig aan om voor de zekerheid zowel verzet als hoger beroep in te stellen, maar dat levert dan uiteraard wel het risico op een proceskostenveroordeling in in ieder geval een van de twee procedures op. Ik zie niet goed waarom ook in dat geval niet een regeling zoals voorzien in art. 340 zou kunnen gelden: de termijn voor het instellen van het juiste rechtsmiddel zou dan aanvangen op het moment dat de opposant door de rechtbank of de appellant door het hof niet-ontvankelijk is verklaard. De wetgever heeft daarvoor evenwel niet gekozen.

Art. 335 lid 2 komt te vervallen. Deze bepaling hing samen met het eerdergenoemde art. 140 lid 3 en schreef voor dat een niet-verschenen verweerder (nog 'gedaagde' geheten) in een geval zoals bedoeld in art. $140 \mathrm{Rv}$ alleen in hoger beroep kan komen indien hij vooraf, tegen het stellen van zekerheid, aan het vonnis voldeed. Dit voorschrift was achterhaald en door de Hoge Raad al grotendeels van zijn kracht beroofd. ${ }^{33}$ De wetgever achtte nu de tijd rijp om het artikel helemaal te schrappen.

\subsection{Beroepstermijn}

De reguliere termijn voor het instellen van hoger beroep van drie maanden is gehandhaafd. Ook hieraan heeft de wetgever dus niet willen tornen, hoewel er wel geluiden waren om de appeltermijn te verkorten tot zes weken en daarmee te uniformeren met de in het bestuursrecht geldende termijnen. ${ }^{34}$ Ook de termijn voor het instellen van hoger beroep in kort geding (lid 2) is ongewijzigd, namelijk vier weken.

Omdat in art. $30 \mathrm{p}$ thans is voorzien in de mogelijkheid om mondeling uitspraak te doen, is aan art. 339 lid 1 toegevoegd, dat in dat geval de termijn wordt gerekend vanaf de dag van de mondelinge uitspraak (en dus niet vanaf de dag waarop het proces-verbaal houdende mondeling vonnis wordt opgemaakt of verstrekt). Omdat een mondelinge uitspraak alleen kan worden gedaan indien alle partijen op de mondelinge behandeling zijn verschenen, zijn alle partijen immers direct van de uitspraak op de hoogte. Voor de beroepstermijn makt het dus niet uit of schriftelijk of mondeling uitspraak wordt gedaan;

31. Daarop is door de Hoge Raad onder omstandigheden een uitzondering aanvaard, zie HR 3 oktober 2014, ECLI:NL:HR:2014:2894, NJ 2016/89 m.nt. Snijders, herhaald in HR 5 juni 2015, ECLI:NL:HR: 2015:1470, JBPr 2015/61 m.nt. Van Rijssen.

32. Zie bijv. Hof Arnhem-Leeuwarden 5 november 2013, ECLI:NL: GHARL:2013:8312, JBPr 2014/20 m.nt. Gras.

33. HR 16 juni 2006, ECLI:NL:HR:2006:AV2644, NJ 2007/462 m.nt. Snijders.

34. Zie Agenda voor de appelrechtspraak 2020, p. 15. de dag van de uitspraak, mondeling of schriftelijk, is bepalend voor het aanvangsmoment. ${ }^{35}$

Termijnen voor het instellen van rechtsmiddelen zijn van openbare orde en daaraan moet strikt de hand worden gehouden. ${ }^{36}$ Dit betreffen dus geen termijnen die de rechter kan verlengen of verkorten. ${ }^{37}$ Omdat art. 30o lid 1 onder a ('Indien dit met het oog op artikel 19 of met het oog op een goede instructie van de zaak noodzakelijk is, kan de rechter (...) bepalen dat termijnen worden verlengd of verkort') in dat verband misverstanden zou kunnen opleveren, is in art. 339 lid 1 uitdrukkelijk bepaald dat de bevoegdheid om termijnen te verlengen of te verkorten geen betrekking heeft op de termijn voor het instellen van hoger beroep.

De partij die beroep in cassatie heeft ingesteld terwijl hoger beroep het geëigende rechtsmiddel was, zal in het cassatieberoep niet-ontvankelijk worden verklaard, maar behoudt de mogelijkheid van het alsnog instellen van hoger beroep, mits het cassatieberoep was ingesteld binnen de voor het hoger beroep geldende termijn. De bepaling dat, indien tijdig beroep in cassatie van een vonnis is ingesteld maar dit vonnis voor cassatie niet vatbaar wordt bevonden, de termijn om van dat vonnis hoger beroep in te stellen opnieuw aanvangt te rekenen van de dag van de uitspraak in cassatie (art. 340) blijft inhoudelijk ongewijzigd.

\subsection{Incidenteel hoger beroep}

Nog altijd geldt als uitgangspunt dat een incidenteel hoger beroep uiterlijk tegelijk met de eerste inhoudelijke reactie van de verweerder moet worden ingesteld. De conclusie van antwoord (in de praktijk memorie van antwoord genoemd) gaat verweerschrift heten (art. 339 lid 3), net zoals in de verzoekprocedure (art. 358 lid 5). Overigens is niet noodzakelijk dat het incidenteel hoger beroep in het verweerschrift zelf wordt opgenomen, het mag ook in een afzonderlijk, eventueel aan het verweerschrift voorafgaand, stuk. ${ }^{38}$ Verweerder is in beginsel in een later dan tegelijk met het verweerschrift ingesteld incidenteel hoger beroep niet-ontvankelijk. De wetgever heeft evenwel onder ogen gezien dat in de rechtspraak onder omstandigheden uitzonderingen op deze regel zijn aanvaard. ${ }^{39}$ Volgens vaste rechtspraak van de Hoge Raad geldt dat de aard van een geschil kan meebrengen dat beide partijen er belang bij hebben dat de beslissing berust op een juiste en volledige waardering van de van belang zijnde omstandigheden zoals die zijn ten tijde van de uitspraak in hoogste ressort, en dat onverkort vasthouden aan voormelde regel daaraan in de weg kan staan. De aard van het geschil kan daarom leiden tot een uit-

35. Zie over de complicaties die zich kunnen voordoen bij de bepaling van wat de dag van de uitspraak is ook de noot van G. van Rijssen onder Rb. 's-Hertogenbosch (vzr.) 23 juni 2008, JBPr 2008/61 en Snijders/ Wendels, Civiel appel, Deventer: Kluwer 2009, nr. 46.

36. Zie bijv. HR 21 februari 2014, ECLI:NL:HR:2014:413 en HR 11 juli 2014, ECLI:NL:HR:2014:1638, JBPr 2014/53.

37. Zie daarover ook HR 20 mei 2011, ECLI:NL:HR:2011:BP6999.

38. HR 7 maart 1986, ECLI:NL:HR:1986:AG5205, NJ 1987/266.

39. Kamerstukken II 2014/15, 34138, 3, p. 25. 
zondering op deze regel, waardoor de appelrechter bij zijn beslissing ook rekening moet houden met (incidentele) grieven die later dan bij verweerschrift zijn aangevoerd. Een dergelijke uitzondering is bijvoorbeeld aanvaard voor alimentatiegeschillen en geschillen aangaande omgangsregelingen. ${ }^{40} \mathrm{Op}$ de zogenoemde tweeconclusieregel (ook wel de in beginsel strakke regel' genoemd) zijn nog meer uitzonderingen aanvaard (zie par. 4.2). Gelet op deze mogelijke uitzonderingen op de hoofdregel zijn de strenge woorden 'op straffe van verval' in art. 339 lid 3 geschrapt. ${ }^{41}$

In art. 339 lid 4 zijn nieuwe voorschriften opgenomen ten aanzien van de wijze waarop afstand van instantie door eiser kan worden gedaan en de wijze waarop verweerder desondanks incidenteel hoger beroep kan instellen. Die zijn nodig omdat de figuur van de rol vervalt en er dus geen 'roldatum' meer is waarop afstand van instantie kan worden gedaan. Zolang de verweerder geen verweerschrift heeft ingediend, kan de eiser afstand doen van instantie (art. 249). Dat moet schriftelijk gebeuren (art. 250). Indien de verweerder nog niet is verschenen, moet de afstand van instantie aan de verweerder op dezelfde wijze worden betekend als het oproepingsbericht in hoger beroep (art. 343 lid 1). Een informele bezorging van de akte is dan dus niet toereikend. Als de verweerder al wel is verschenen, zal hij via het digitale systeem een bericht ontvangen en raakt hij op die wijze op de hoogte van de afstand van instantie, waarna hij binnen twee weken kan aangeven dat hij incidenteel hoger beroep wil instellen. De rechter zal in de regel een termijn van tien weken geven voor het indienen van de gronden van het incidenteel hoger beroep (vergelijk art. 343 lid 3), welke gronden vervolgens binnen twee weken na indiening moeten worden betekend bij de wederpartij. Omdat de wederpartij na de afstand van instantie de zaak als afgedaan kan beschouwen, is het ook hier van belang dat de gronden voor het incidenteel hoger beroep bij haar worden betekend en niet informeel worden bezorgd.

\subsection{Reconventie en vrijwaring niet voor het eerst in hoger beroep}

Art. 353 lid 1 is thans geheel gewijd aan de bepaling dat in hoger beroep niet voor het eerst een vordering in reconventie kan worden ingesteld. Dit werd al afgeleid uit het inmiddels vervallen art. 137 (waarin was bepaald dat de eis in reconventie dadelijk bij antwoord moet worden ingesteld) en was als bijzin in lid 1 van art. 353 opgenomen. Dat in art. 353, dat onderdeel uitmaakt van de afdeling die handelt over de vorderingsprocedure, ook is bepaald dat in hoger beroep niet voor het eerst een tegenverzoek kan worden gedaan, zal ermee te maken hebben dat op een gecombineerde procedure (zie art. $30 \mathrm{~b}$ en 343 lid 2) in beginsel de regels van de vorderingsproce-

40. HR 20 maart 2009, ECLI:NL:HR:2009:BG9917, NJ 2010/153 m.nt. Snijders en HR 28 september 2012, ECLI:NL:HR:2012:BW9226, NJ 2012/552.

41. In art. 358 lid 5 (incidenteel hoger beroep in verzoekprocedures) stonden deze woorden al niet. dure van toepassing zijn. In verzoekprocedures geldt overigens hetzelfde (art. 362).

De wetgever heeft de wetswijziging aangegrepen om een eerdere omissie te herstellen. De oude leer dat het onmogelijk was om voor het eerst in hoger beroep een derde in vrijwaring op te roepen, was bij de wetswijziging van 1 januari $2002 \mathrm{abu}$ sievelijk niet meegenomen. In de rechtspraak is men er altijd van uitgegaan dat de wetgever van 2002 niet heeft bedoeld met de oude leer te breken. ${ }^{42}$ Inmiddels staat het met zoveel woorden in art. 353 lid 2.

\section{Indiening en betekening}

\subsection{Digitale indiening}

Het hoger beroep wordt aanhangig vanaf het moment dat de procesinleiding bij de rechter (via een door de rechtspraak ontwikkeld webportaal) is ingediend (art. 30a lid 1 jo. art. 30c lid 1). ${ }^{43}$ Omdat ingevolge art. 353 lid 2 in hoger beroep in vorderingsprocedures slechts bij advocaat kan worden geprocedeerd, geldt in alle gevallen dat de procesinleiding in hoger beroep in vorderingsprocedures digitaal zal moeten worden ingediend (art. 30c lid 1). Het ten onrechte indienen van een procesinleiding op papier leidt in beginsel tot niet-ontvankelijkheid (art. 30c lid 8), zij het dat de rechter op grond van art. 30c lid 6 eerst een mogelijkheid tot herstel van dit verzuim moet bieden binnen een door hem te bepalen termijn. Ook de indiening van het verweerschrift en de overige stukkenwisselingen en mededelingen vinden langs digitale weg plaats. De uitzondering van art. 30c lid 4 op de verplichting om de procesinleiding (en overige stukken) langs elektronische weg in te dienen, die geldt voor natuurlijke personen en informele verenigingen die niet worden vertegenwoordigd door een professionele rechtsbijstandverlener, doet zich in vorderingsprocedures in hoger beroep niet voor, omdat bijstand door een advocaat verplicht is.

In verzoekprocedures geldt dat de procesinleiding in beginsel door een advocaat moet worden ondertekend en ingediend (art. 30a lid 4 jo. art. 279 jo. art. 362). Onder het huidige procesrecht houdt de verplichte procesvertegenwoordiging daarmee op. ${ }^{44}$ Daarmee verschilde de verzoekschriftprocedure dus van de dagvaardingsprocedure. In de verzoekschriftprocedure was de verplichting tot bijstand van een advocaat beperkt tot het verzoek- en verweerschrift, ${ }^{45}$ in de dagvaardingsprocedure strekte de verplichte procesvertegenwoordiging zich uit tot alle proceshandelingen (met dien verstande dat een partij wel

42. HR 14 december 2007, ECLI:NL:HR:2007:BB7189, NJ 2008/9.

43. Kamerstukken II 2014/15, 34138, 3, p. 5 en 16.

44. Concl. A-G Langemeijer voor HR 26 juni 2009, ECLI:NL:HR 2009:BH9287, onder 2.7.

45. Hoewel HR 26 juni 2009, ECLI:NL:HR:2009:BH9287, NJ 2010/127 m.nt. Snijders nog anders leek te suggereren, waar de Hoge Raad overwoog dat in verzoekschriftprocedures waarin voor de partijen verplichte procesvertegenwoordiging geldt, partijen zich bij het verrichten van formele proceshandelingen, zoals het indienen van een verzoekschrift en een verweerschrift, zich laten vertegenwoordigen door (destijds een procureur, nu) een advocaat. Wat onder formele proceshandelingen diende te worden verstaan, bleef evenwel onduidelijk. 
zelf haar zaak mocht bepleiten). In het algemeen wordt aangenomen dat in de verzoekschriftprocedure dus een beperkte procesvertegenwoordigingsplicht geldt, die meebrengt dat afgezien van het ondertekenen van een (aanvullend) verzoekschrift of verweerschrift geen procesvertegenwoordiging door een advocaat vereist is voor andere handelingen, zoals het overleggen van stukken, de indiening van een nadere toelichting of het corresponderen met de desbetreffende gerechtelijke instantie. ${ }^{46}$ Ten aanzien van de verschijning ter mondelinge behandeling wordt dit in het huidige art. 279 lid 3 nog eens uitdrukkelijk bepaald. Het is de vraag of dit met het nieuwe art. 279 is veranderd. Daarin is bepaald dat partijen in bepaalde verzoekprocedures in persoon kunnen procederen en in alle overige zaken slechts bij advocaat. 'Bij advocaat procederen' is ruimer dan dat de procesinleiding en het verweerschrift bij advocaat moeten worden ingediend; dit lijkt ook alle daaropvolgende (formele) proceshandelingen te omvatten. ${ }^{47}$ In art. $30 \mathrm{k}$ wordt ook zonder uitzondering voor de verzoekprocedure bepaald dat partijen in zaken waarin zij niet in persoon kunnen procederen bij advocaat verschijnen (met uitzondering van belanghebbenden). De wettekst lijkt dus te suggereren dat ook in de verzoekprocedure (behalve de in art. 279 bedoelde uitgezonderde zaken) een algehele procesvertegenwoordigingsplicht geldt voor verzoeker en verweerder. De uitzondering op verplicht digitaal procederen zal in hoger beroep dan alleen nog voor belanghebbenden in verzoekprocedures van belang zijn. ${ }^{48}$ Dat zou stroken met de wens van de wetgever om vorderings- en verzoekprocedures zo veel mogelijk te uniformeren en om procedures zo veel mogelijk digitaal te laten verlopen. Anderzijds volgt uit de memorie van toelichting dat de wetgever niet heeft bedoeld te breken met de huidige regels en praktijk ter zake; in de ogen van de wetgever blijven de regels inzake procesvertegenwoordiging hetzelfde. ${ }^{49}$ Het lijkt erop dat de wetgever niet scherp voor ogen heeft gehad dat in de verzoekprocedure de huidige regels van verplichte procesvertegenwoordiging beperkt zijn tot indiening van beroep- en verweerschrift. Het is mij onduidelijk welke wens voor de wetgever zwaarder heeft gewogen: de wens tot uniformering of juist de wens om niet met de huidige regels en praktijk te breken. Vooralsnog neig ik ernaar om de laatste, in dit verband in de wetsgeschiedenis uitdrukkelijk genoemde, wens de doorslag te laten geven en ga ik ervan uit dat de huidige praktijk kan worden voortgezet.

\subsection{Oproepingsbericht}

De verplichting tot het betekenen van een dagvaarding bij exploot in vorderingsprocedures wordt opgeheven. Nadat de

46. Zie hierover concl. A-G Rank-Berenschot voor HR 25 september 2015 , ECLI:NL:PHR:2015:845 en eerder al concl. A-G Langemeijer voor HR 26 juni 2009, ECLI:NL:HR:2009:BH9287, onder 2.7; zie ook H.J. Snijders, C.J.M. Klaassen \& G.J. Meijer, Nederlands burgerlijk procesrecht, Deventer: Kluwer 2011, nr. 300.

47. Vgl. het eerder aangehaalde HR 26 juni 2009, ECLI:NL:HR 2009:BH9287, NJ 2010/127 m.nt. Snijders.

48. In deze zin de algemene inleiding op de MvT: Kamerstukken II $2014 / 15,34138,3$, p. 2.

49. Kamerstukken II 2014/15, 34059, 3, p. 72. procesinleiding is ingediend, ontvangt de eiser van de griffier een oproepingsbericht (art. 111). Vervolgens moet dat oproepingsbericht - waarvan de procesinleiding deel uitmaakt binnen twee weken aan de wederpartij worden bezorgd of betekend. In art. 112 is voorzien in een informele bekendmaking van de procesinleiding aan de wederpartij, zonder tussenkomst van een deurwaarder. Die mogelijkheid geldt ook in hoger beroep. De eiser in hoger beroep kan het oproepingsbericht dus bijvoorbeeld per post, koerier, faxbericht of e-mail aan de wederpartij sturen. Vooral in de gevallen waarin de wederpartij in eerste aanleg werd bijgestaan door een advocaat zal een informele oproeping een bruikbare optie zijn, door bekendmaking aan (het kantoor van) die advocaat (art. 63).50 Dat geldt ook als een partij inmiddels van advocaat is gewisseld; de advocaat in eerste aanleg dient het oproepingsbericht dan op grond van art. 63 (dat ingevolge art. 343 lid 6 ook in hoger beroep van toepassing is) aan zijn voormalige cliënt door te geleiden. Het lijkt wel raadzaam om in geval van informele bezorging van de (advocaat van de) wederpartij een bevestiging te vragen dat zij zal verschijnen. Indien de wederpartij op een informele oproeping niet verschijnt, zal de rechter namelijk nog geen verstek mogen verlenen en zal alsnog betekening door de deurwaarder moeten plaatsvinden (art. 112 lid 2). Overigens zal ook dat op grond van art. 63 kunnen plaatsvinden aan het kantoor van de advocaat waar de partij in eerste aanleg woonplaats heeft gekozen. Bij het ontbreken van een bevestiging dat men vrijwillig zal verschijnen, kan tijdverlies worden voorkomen door dan alsnog direct de wederpartij bij deurwaarder op te roepen. De betekening van het oproepingsbericht zal - anders dan in eerste aanleg (art. 113) - niet al vóór de indiening bij de rechter kunnen gebeuren. Art. 113 is ingevolge art. 343 lid 6 namelijk niet van toepassing op het instellen van hoger beroep.

Bij het indienen van de procesinleiding kiest de eiser, net als in eerste aanleg, een termijn voor de verweerder om in hoger beroep te verschijnen. Deze termijn bedraagt minimaal vier weken en maximaal zes maanden na de dag van indiening van de procesinleiding (art. 30a lid 3 onder c). ${ }^{51}$ De eiser heeft dus een maximale termijn van twee weken om de verweerder op formele of informele wijze op de hoogte te stellen van het hoger beroep en de verweerder heeft dan vervolgens nog minimaal twee weken om te verschijnen. Overigens zal de verweerder, net als in eerste aanleg, de oproepingstermijn kunnen verkorten door eerder te verschijnen.

Indien de eiser voor een informele wijze van oproeping heeft gekozen en de verweerder op de aangezegde dag niet verschijnt, zal de rechter geen verstek mogen verlenen en moet de verweerder alsnog bij exploot worden opgeroepen. Daarvoor heeft de eiser twee weken de tijd. De nieuwe verschijningsda-

50. Kamerstukken II 2014/15, 34138, 3, p. 29.

51. Zie over de complicaties die de termijnenregeling met name bij buitenlandse partijen met zich kan brengen de bijdrage van Tjong Tjin Tai in dit nummer. 
tum ligt vier weken na de oorspronkelijke verschijningsdatum (art. 112 lid 2).

Verder behoeft, anders dan in eerste aanleg, het oproepingsbericht in hoger beroep niet de dag te vermelden wanneer de verweerder in hoger beroep uiterlijk zijn verweerschrift kan indienen (art. 343 lid 5). Dat is immers dan nog niet bekend, omdat die dag afhankelijk is van het door de rechter nog te bepalen moment waarop de termijn voor het aanvoeren van de gronden van het hoger beroep aanvangt (art. 343 lid 3). De ingevolge art. 347 toepasselijke termijn voor het indienen van het verweerschrift (tien weken in een bodemzaak, vier weken in een kort geding) moet wel worden genoemd. Heel zinvol lijkt dat overigens niet, aangezien het aanvangsmoment van die termijn dan nog niet bekend is.

Ook behoeven, anders dan in eerste aanleg, in het oproepingsbericht niet te worden genoemd de in art. 139 genoemde rechtsgevolgen die intreden indien de verweerder bij een vordering niet verschijnt in de procedure als verweerder als bedoeld in art. 114. In hoger beroep geldt namelijk niet onverkort de regel dat bij het niet verschijnen van de verweerder de rechter de vordering toewijst, tenzij deze hem onrechtmatig of ongegrond voorkomt. Dat was in het huidige art. 343 ook al zo bepaald.

In de verzoekprocedure geldt een andere regeling. Die procedure kent niet een oproepingsbericht in de zin van art. 111 en de bezorging of betekening daarvan door de eiser, maar alleen een oproeping door de griffier van het gerecht (art. 271). Als een verzoeker alle belanghebbenden zelf zou moeten oproepen, zou dit te veel kosten voor hem kunnen meebrengen. Bovendien zou het gerechtshof dan moeten controleren of de verzoeker inderdaad wel alle belanghebbenden heeft opgeroepen. Het werd daarom efficiënter geacht dat het gerechtshof dan maar zelf alle belanghebbenden blijft oproepen. ${ }^{52}$

\section{Wettelijke termijnen voor proceshandelingen}

\subsection{Processtukken van partijen}

De termijnen voor het indienen van de memorie van grieven en de memorie van antwoord en de uitstelmogelijkheden worden thans gereguleerd door het procesreglement van de hoven (Landelijk procesreglement voor civiele dagvaardingszaken bij de gerechtshoven). Daarbij hanteren sommige hoven hun eigen 'pilotreglement'. In art. 343 lid 3 en 347 lid 2 worden die termijnen wettelijk vastgelegd en bepaald op tien weken voor bodemzaken en op vier weken voor kort geding.

De termijn voor het indienen van de gronden gaat lopen op het door de rechter daartoe bepaalde moment. Dit geeft de rechter ruimte voor het voeren van regie. $\mathrm{Na}$ indiening van de procesinleiding kan de rechter beoordelen of er bijvoorbeeld aanleiding is om eerst over de ontvankelijkheid te oordelen of

52. Kamerstukken II 2014/15, 34138, 3, p. 8 . om eerst op een incident te beslissen, voordat de eiser in hoger beroep zijn (inhoudelijke) gronden van het hoger beroep aanvoert. Ook biedt dit gelegenheid om te beoordelen of de zaak zich leent voor een comparitie na aanbrengen. Voor deze in de afgelopen jaren gegroeide praktijk van de hoven om direct na aanbrengen van een zaak in hoger beroep met partijen van gedachten te wisselen met het oog op het bereiken van een schikking, het inwinnen van informatie of het stroomlijnen van de procedure in hoger beroep ${ }^{53}$ heeft de wetgever blijkens de memorie van toelichting uitdrukkelijk ruimte willen laten. In de genoemde voorbeelden kan de rechter nadat over de ontvankelijkheid (positief) is beslist, nadat op het incident is beslist of aan het einde of kort na afloop van de comparitie na aanbrengen beslissen dat de termijn voor het indienen van de gronden ingaat.

Nadat de eiser in hoger beroep zijn gronden heeft ingediend, heeft de verweerder in hoger beroep eveneens een termijn van tien respectievelijk vier weken om zijn verweer in te dienen. Voor het verweerschrift in incidenteel hoger beroep gelden dezelfde termijnen. De merkwaardige toevoeging dat eiser 'op zijn verlangen' een termijn krijgt voor het indienen van schriftelijk verweer is blijven staan. In de praktijk wordt altijd gelegenheid gegeven voor het indienen van (wat wordt genoemd) een memorie van antwoord in incidenteel hoger beroep. Daartoe hoeft niet eerst een verzoek te worden gedaan.

In uitstelmogelijkheden in hoger beroep is niet uitdrukkelijk voorzien. Daarvoor moet worden teruggevallen op art. 30o lid 1 aanhef en onder a. Volgens die bepaling kan de rechter termijnen verlengen (of verkorten) indien dit met het oog op art. 19 (beginsel van hoor en wederhoor) of met het oog op een goede instructie van de zaak noodzakelijk is. In de wetsgeschiedenis worden in dit verband de voorbeelden genoemd van een nog te verrichten deskundigenonderzoek/second opinion, de afwikkeling van een faillissement of een andere procedure of de vertaling van stukken voor buitenlandse partijen. ${ }^{54}$ Aangenomen mag worden dat dit ook de mogelijkheid omvat dat de rechter uitstel verleent wegens klemmende redenen die zich aan de zijde van partijen voordoen. ${ }^{55} \mathrm{Er}$ is overwogen om een vaste termijn voor uitstel op te nemen, maar daarvan is afgezien omdat de omstandigheden die aanleiding geven tot uitstel te veel kunnen verschillen. Blijkens de memorie van toelichting kunnen de termijnen die als uitgangspunt dienen indien partijen om uitstel verzoeken, nader worden uitgewerkt in een landelijk uniform procesreglement.

Het Gerechtshof Amsterdam hanteert onder het huidige procesrecht een procesreglement waarbij voor de memorie van grieven slechts eenmalig een termijn van zes weken geldt. Ingevolge dat reglement wordt - voor zover thans relevant - alleen uitstel verleend op eenstemmig verzoek van partijen of op ver-

53. Zie hierover ook hetgeen ik hierboven schreef in par. 2.3 .

54. Kamerstukken II 2014/15, 34138, 3, p. 13 en 27.

55. Zie ook Kamerstukken II 2014/15, 34059, 3, p. 68, waar het voorbeeld van ziekte wordt genoemd. 
zoek van een partij op grond van klemmende redenen. $\mathrm{Bij}$ overschrijding van de termijn wordt ambtshalve akte niet-dienen verleend. De Hoge Raad heeft hierover overwogen dat voor zover strikte naleving van het reglement meebrengt dat de appellanten door het verzuim van hun advocaat definitief hun zaak niet in hoger beroep aan de rechter kunnen voorleggen, zeker nu de toegang tot de (appel)rechter in het geding is, de sanctie op het niet in acht nemen van de termijnen van het pilotreglement in een redelijke verhouding dient te staan tot het verzuim. Een goede procesorde brengt, aldus de Hoge Raad, mee dat het belang van het voorkomen van onredelijke vertraging van het geding moet worden afgewogen tegen de ernst van het verzuim en de gevolgen die strikte naleving van het reglement zou hebben voor de procesvoering van de partij die erdoor wordt getroffen. Art. 1.6 van het pilotreglement maakte die afweging ook mogelijk. De Hoge Raad oordeelde dat die afweging zonder meer diende te leiden tot het verlenen van een (korte) termijn van veertien dagen om het verzuim te herstellen, ${ }^{56}$ zelfs als daar door de partij die het aangaat niet om is verzocht. ${ }^{57}$ Het is de vraag in hoeverre deze jurisprudentie, die niet op zichzelf staat, ${ }^{58}$ haar zeggingskracht behoudt, nu de (eenmalige) termijn voor het aanvoeren van de gronden van het hoger beroep niet in een procesreglement staat maar in de wet is vastgelegd.

In dit verband is het interessant om een parallel te trekken met de (eenvormige) Wetboeken van Burgerlijke Rechtsvordering van de Caribische gebiedsdelen van het Koninkrijk (hierna: RvCar). Ingevolge art. 264 jo. art. 270 RvCar moet binnen zes weken, gerekend van de dag van de uitspraak, hoger beroep worden ingesteld door het ter griffie afleggen van een daartoe strekkende verklaring. Ingevolge art. $271 \mathrm{RvCar}$ is de appellant bevoegd om binnen uiterlijk zes weken na de dag van deze verklaring een ondertekende memorie, houdende de middelen waarop het hoger beroep is gegrond, in te dienen. Van deze termijn voor het indienen van de memorie van grieven is geen uitstel mogelijk. De Hoge Raad heeft geoordeeld dat dit voorschrift van openbare orde is; de termijn mag in geen geval worden overschreden en het hof moet ambtshalve beoordelen of de memorie van grieven binnen de termijn is ingediend. ${ }^{59} \mathrm{Op}$ de inhoud van een buiten de termijn ingediende memorie van grieven mag geen acht worden geslagen. ${ }^{60}$ Dezelfde regeling geldt voor het indienen van de andere memories (art. 274 lid 1 en 275 lid 2 RvCar).

56. HR 17 april 2015, ECLI:NL:HR:2015:1075, zie ook HR 4 maart 2016, ECLI:NL:HR:2016:376.

57. HR 8 april 2016, ECLI:NL:HR:2016:606.

58. Zie bijv. ook ten aanzien van het Bossche pilotreglement HR 17 april 2015, ECLI:NL:HR:2015:1064, met een gelijke strekking.

59. HR 8 december 1995, ECLI:NL:HR:1995:ZC1915, NJ 1996/273 en concl. A-G Bakels voor HR 9 juli 1999, ECLI:NL:HR:1999:ZC2953, NJ 1999/699.

60. Maar mede gelet op de korte, niet-verlengbare termijn voor het indienen van een memorie van grieven moet de appellant dan nog wel de gelegenheid kriigen om zijn zaak mondeling te bepleiten: HR 10 november 2000, ECLI:NL:HR:2000:AA8289, NJ 2001/301.
Het komt mij voor dat deze rechtspraak, die mede is ingegeven door het eigen karakter van RvCar en het ontbreken van een grievenstelsel (de rechter mag ook zonder grieven of buiten de grieven om vernietigen ${ }^{61}$ ), niet zonder meer ook van toepassing is op art. 343. Met name de mogelijkheden die, anders dan in RvCar, in art. 30o worden geboden om van de wettelijke termijn af te wijken en het feit dat onder het Nederlandse grievenstelsel het ontbreken van grieven in de meeste gevallen (ambtshalve toetsing aan bepalingen van openbare orde of daaraan gelijk te stellen regels daargelaten) tot niet-ontvankelijkheid of het verwerpen van het hoger beroep dient te leiden, zal betekenen dat de appelrechter van geval tot geval zal moeten afwegen of uitstel van de termijn geboden is. Daarbij zal de rechter enerzijds moeten letten op het belang van het voorkomen van onredelijke vertraging van het geding en anderzijds op de gevolgen die het niet-verlenen van uitstel zou hebben voor de mogelijkheid om de zaak in hoger beroep aan de rechter te kunnen voorleggen en voor de procesvoering van de partij die erdoor wordt getroffen. Van termijnen van openbare orde 'waarvan in geen geval mag worden afgeweken', is geen sprake. De termijn van tien weken vormt wel een duidelijk uitgangspunt en richtsnoer waaraan partijen zich in beginsel hebben te houden.

Voor wat betreft de termijnen in de verzoekprocedure blijft de wet vrijwel ongewijzigd. Een afzonderlijke termijn voor het indienen van de gronden van het hoger beroep is niet nodig, aangezien die gronden reeds moeten zijn opgenomen in de procesinleiding (zie hiervoor). De termijn voor het indienen van een verweerschrift voor opgeroepen belanghebbenden blijft ongewijzigd vier weken, aan te vangen nadat een afschrift van de procesinleiding in hoger beroep is toegezonden (art. 361 lid 3). Ook van deze termijn kan op grond van art. 30o worden afgeweken. Voor niet-opgeroepen belanghebbenden geldt overigens niet langer dat het verweerschrift nog tot de aanvang van de mondelinge behandeling kan worden ingediend. Het ook in hoger beroep toepasselijke art. 282 bepaalt dat dit kan tot tien dagen voor de mondelinge behandeling of, indien de rechter dit toestaat, op een later moment, tenzij de wet een andere termijn voorschrijft. Daarbij zal nog steeds gelden dat indien de rechter van oordeel is dat een tijdig ingediend verweerschrift te omvangrijk of niet eenvoudig te doorgronden is, hij maatregelen moet treffen om te waarborgen dat de wederpartij voldoende gelegenheid heeft om dat stuk te bestuderen. ${ }^{62}$ Ook voor het verweer in een incidenteel hoger beroep geldt een termijn van vier weken, na de indiening van het verweerschrift waarbij het incidenteel hoger beroep is ingesteld (art. 361 lid 4). Bij dit laatstgenoemde aanvangsmoment lijkt overigens over het hoofd te zijn gezien dat een incidenteel hoger beroep niet alleen bij verweerschrift, maar ook

61. Zie over dit zogenoemde 'gematigde grievenstelsel': G.C.C. Lewin, Het hoger beroep en het cassatieberoep in burgerlijke zaken in de Nederlandse Antillen en Aruba (diss. Willemstad, Curaçao), Deventer: Kluwer 2010 en Ras/Hammerstein/Lewin, De grenzen van de rechtsstrijd in hoger beroep in burgerlijke zaken in de Nederlandse Antillen en Aruba, Deventer: Kluwer 2008.

62. HR 29 januari 2016, ECLI:NL:HR:2016:155. 
afzonderlijk kan worden ingesteld en onder omstandigheden zelfs nog tijdens de mondelinge behandeling (zie par. 2.7). De rechter zal ervoor moeten waken dat ook in die gevallen gelegenheid wordt geboden voor verweer in het incidenteel hoger beroep.

De wettelijke termijnen voor proceshandelingen door partijen zijn niet alleen beperkt tot het indienen van de gronden en het verweer. Ook voor het indienen van stukken ten behoeve van een mondelinge behandeling is een wettelijke termijn van tien dagen geïntroduceerd (art. 30k lid 5). Thans is dit nog in het procesreglement geregeld. Ten aanzien van die termijn (eerst nog vier dagen, later verlengd tot veertien dagen vóór de zitting) heeft de Hoge Raad overwogen dat de procesreglementen weliswaar aanwijzingen geven voor het tijdig indienen van stukken, maar dat dit niet wil zeggen dat indien de aanwijzingen zijn gevolgd per definitie is voldaan aan het beginsel van hoor en wederhoor waarop de regels zijn gebaseerd. Wel kan aan de in een procesreglement gestelde termijn voor indiening van nadere stukken het uitgangspunt worden ontleend dat in het algemeen indiening van nadere stukken (ruimschoots) voor het in het procesreglement bedoelde tijdstip heeft te gelden als zodanig tijdig dat de wederpartij er voldoende van kennis zal kunnen nemen om er adequaat op te kunnen reageren, zo nodig met een gemotiveerd verzoek om aanhouding van de behandeling van de zaak, dan wel om bij nadere akte op de ingediende stukken te mogen reageren. Dit brengt mee dat de rechter op binnen de geldende termijn overgelegde nadere stukken bij de beoordeling acht dient te slaan, tenzij de rechter - naar aanleiding van het door de wederpartij daartegen gemaakt bezwaar of ambtshalve - gemotiveerd anders beslist op grond van de bijzondere omstandigheden van het geval, waarvan uit de uitspraak of het proces-verbaal van de zitting dient te blijken. Daarbij zal de rechter hebben te beoordelen of het gaat om stukken waarvan de aard en omvang een beletsel vormen om daarvan binnen de beschikbare tijd kennis te nemen en daarop adequaat te reageren, en, zo dat niet van de wederpartij kon worden gevergd, of aanleiding bestaat een maatregel te treffen teneinde een voldoende kennisneming en voorbereiding van een reactie alsnog mogelijk te maken. Hierbij kan van belang zijn of met het oog op het belang van de wederpartij verwacht had mogen worden dat de stukken bij een eerdere gelegenheid in de procedure werden overgelegd, en dat, zeker in de procedure in hoger beroep, de pleitzitting in het algemeen de laatste gelegenheid zal zijn tot nadere feitelijke onderbouwing van een vordering of verweer. ${ }^{63}$ In haar annotatie onder dit arrest legt Teuben de uitspraak van de Hoge Raad vooral uit in het licht van het karakter van het procesreglement, dat regels van lagere rangorde bevat dan bijvoorbeeld wettelijke regels. Dat neemt niet weg dat dit arrest van de Hoge Raad mijns inziens ook relevantie voor de nieuwe wettelijke termijn heeft. Art. 30k lid 5 biedt zelf al een mogelijkheid aan de rechter om stukken die na de termijn worden ingediend toch niet buiten beschouwing te laten indien rede-

63. HR 3 december 2010, ECLI:NL:HR:2010:BO0197, JBPr 2011/16 m.nt. Teuben. lijkerwijs niet kan worden geoordeeld dat de indiener in verzuim is of de goede procesorde zich daartegen verzet. Blijkens de memorie van toelichting geldt voorts dat het mogelijk is dat een stuk dat tijdig binnen de termijn is ingediend niettemin in strijd kan zijn met de goede procesorde als het een zeer omvangrijk stuk is waarover de indiener al beschikte. ${ }^{64}$ Ook de wettelijke termijn is naar de bedoeling van de wetgever dus geen harde termijn; afwijking naar beide kanten is mogelijk.

De wettelijke termijn voor het opgeven van de gegevens van de te horen getuigen en het oproepen van de getuigen is in art. 170 verlengd van een week tot eveneens tien dagen. ${ }^{65}$ Ook daarvoor zal gelden dat de jurisprudentie van de Hoge Raad over het al dan niet strikt hanteren van deze termijn haar zeggingskracht behoudt. ${ }^{66}$

Voor veel andere denkbare proceshandelingen zal ook onder het nieuwe procesrecht nog steeds een procesreglement nodig zijn. Er wordt in dat verband gewerkt aan een uniform procesreglement voor zowel eerste aanleg als hoger beroep, waarbij er uiteraard aandacht zal zijn voor de verschillen tussen beide procedures.

\subsection{Tweeconclusieregel}

De nieuw gekozen bewoordingen van art. 347 lid 1 ('Beide partijen krijgen in hoger beroep eenmaal de gelegenheid de gronden van het beroep en het verweer schriftelijk uiteen te zetten') brengen nog duidelijker tot uitdrukking dat in hoger beroep als regel geldt dat partijen elk één processtuk mogen indienen. Op deze zogenoemde 'tweeconclusieregel' of 'in beginsel strakke regel' zijn in de rechtspraak diverse uitzonderingen aanvaard; ik schreef hierover reeds in het verband van het incidenteel hoger beroep. Dit is met name het geval indien de wederpartij ondubbelzinnig erin heeft toegestemd dat er nog nieuwe gronden of verweren worden aangevoerd of dat er nog een eisverandering of -vermeerdering plaatsvindt, of indien de aard van het geschil meebrengt dat in een later stadium nog zodanige verandering of aanvulling kan plaatsvinden. Verder kan in het algemeen een nieuwe grief of een nieuw verweer na het tijdstip van de memorie van grieven of antwoord toelaatbaar zijn indien daarmee aanpassing wordt beoogd aan eerst na dat tijdstip voorgevallen of gebleken feiten en omstandigheden en de nieuwe grief of het nieuwe verweer ertoe strekt te voorkomen dat het geschil aan de hand van inmiddels achterhaalde of onjuist gebleken (juridische of feitelijke) gegevens zou moeten worden beslist, of dat - indien dan nog mogelijk een nieuwe procedure zou moeten worden aangespannen om het geschil alsnog aan de hand van de juiste en volledige gegevens te kunnen doen beslissen. Onverkort blijft dan gelden dat

64. Kamerstukken II 2014/15, 34059, 3, p. 72.

65. Kamerstukken II 2014/15, 34059, 2, p. 21. Zie ook Kamerstukken II 2014/15, 34059, 3, p. 97.

66. HR 18 maart 2011, ECLI:NL:HR:2011:BP0571, NJ 2012/315 m.nt Klaassen. Zie hierover ook G. de Groot, Getuigenbewijs in civiele zaken, Deventer: Wolters Kluwer 2015, p. 64. 
dit niet in strijd mag komen met de eisen van een goede procesorde. $^{67}$

Waar in de memorie van toelichting wordt vermeld dat op de tweeconclusieregel op basis van de huidige jurisprudentie een uitzondering mogelijk is indien sprake is van nova, ${ }^{68}$ is die dus niet compleet. Wel wordt uit de toelichting duidelijk dat de wetgever art. 347 lid 1 als hoofdregel ziet en dat daarop nog altijd uitzonderingen mogelijk zijn. Art. 30o lid 1 onder b, dat van toepassing in hoger beroep niet is uitgesloten, geeft de rechter daarvoor ook uitdrukkelijk een handvat. De rechter kan partijen de gelegenheid geven om nader schriftelijk te reageren op elkaars standpunten. Overigens zou dat volgens de memorie van toelichting voor de rechter een signaal moeten zijn dat er een mondelinge behandeling gehouden dient te worden. ${ }^{69}$

\subsection{Uitspraaktermijn}

De rechter doet uitspraak binnen tien weken na de datum van mondelinge behandeling of de laatste proceshandeling. In geval van kort geding geldt een termijn van zes weken. Art. 357 lid 1, dat dit bepaalt, is nieuw. Niet eerder was in de wet een termijn voor het doen van uitspraak vastgelegd. Het is de bedoeling dat van de in de wet vastgelegde uitspraaktermijnen een normerende werking uitgaat. Op overschrijding van de termijn staat geen sanctie. De uitspraaktermijnen zijn in hoger beroep iets langer dan in eerste aanleg (art. 30q lid 1). De rechtvaardiging voor de langere termijn in hoger beroep ten opzichte van de eerste aanleg is erin gelegen dat in hoger beroep meervoudig wordt beslist en de gemiddelde complexiteit van de zaak groter is. De uitspraaktermijn moet worden gezien als een maximumtermijn. Eerder uitspraak doen mag, zoals blijkt uit de bewoordingen dat de rechter uitspraak doet 'binnen' tien respectievelijk zes weken. Overeenkomstig de huidige praktijk mag de rechter ook eerder ('bij vervroeging') uitspraak doen dan op de datum die hij heeft bepaald. Bij sommige hoven wordt dit van tevoren aan partijen bekendgemaakt omdat een toegezegde datum van invloed kan zijn op een eventueel schikkingsproces en omdat het daarnaast vanwege de beroeps- en cassatietermijn van belang is dat partijen weten dat de uitspraak eerder wordt gedaan. In verstekzaken wordt veelal niet bij vervroeging uitspraak gedaan (vergelijk art. 6.4 lid 4 van het Landelijk procesreglement voor civiele dagvaardingszaken bij de rechtbanken; de hoven hebben dit gebruik niet gecodificeerd) omdat daarmee de mogelijkheid om het verstek nog te zuiveren tekortgedaan zou worden.

Er is geen onderscheid gemaakt tussen een uitspraak in de hoofdzaak en een uitspraak in een incident. In het geval van bepaalde incidenten (zoals een schorsingsincident of een pro-

67. Zie voor een overzicht van deze jurisprudentie concl. A-G Wesselingvan Gent voor HR 28 september 2012, ECLI:NL:HR:2012:BW9226, NJ 2012/552 en B.T.M. van der Wiel, De in beginsel strakke regel, TCR 2012, afl. 3, p. 71 e.v.

68. Kamerstukken II 2014/15, 34138, 3, p. 30.

69. Ibid. visionele vordering) ligt het voor de hand dat de rechter een kortere dan de maximale termijn zal hanteren voor het doen van een uitspraak.

Uit de tekst van art. 30q lid 1 volgt dat partijen niet om arrest hoeven te vragen; het vragen om een uitspraak als zodanig is geschrapt. ${ }^{70}$ De rechter bepaalt (ambtshalve) na afloop van de mondelinge behandeling of nadat de laatste proceshandeling is verricht, dat uitspraak zal worden gedaan. Wel kunnen partijen gezamenlijk de rechter verzoeken de uitspraak uit te stellen of achterwege te laten (lid 3). Dat zal met name het geval zijn indien partijen in overleg zijn over een minnelijke regeling of inmiddels een schikking hebben bereikt. In de memorie van toelichting is vermeld dat indien partijen niet om een arrest verzoeken, de procedure wordt aangehouden, maar het is onduidelijk waarop dit is gebaseerd en het strookt niet met het schrappen van het vragen om een uitspraak door partijen.

Ook in de verzoekprocedure geldt een wettelijke uitspraaktermijn, en wel van zes weken na de datum van mondelinge behandeling of (andere) laatste proceshandeling (art. 361a).

Hetgeen in art. $30 \mathrm{q}$ (lid 2 ) is bepaald over de verlenging van de termijn voor de uitspraak is ook in hoger beroep van toepassing. In bijzondere omstandigheden kan de rechter de termijn voor het doen van uitspraak verlengen. Bij een verlenging wordt mededeling gedaan aan partijen van de nieuwe uitspraakdatum.

\section{Behandeling door de rechter; regie}

\subsection{Enkelvoudige en meervoudige kamer}

Uitgangspunt is dat zaken in hoger beroep door een meervoudige kamer worden behandeld en beslist (art. 81 lid 2 van de Wet op de rechterlijke organisatie en art. $16 \mathrm{Rv}$ ).

Art. 344 bepaalt dat alle zaken die in hoger beroep aanhangig worden gemaakt door een enkelvoudige kamer in behandeling worden genomen. Deze bepaling is van oudsher bedoeld om het functioneren van een (enkelvoudige) rolraadsheer mogelijk te maken. De rolraadsheer nam op de rol beslissingen over de orde van het geding, zoals het stellen van termijnen, het toelaten van aktes en het toestaan van pleidooi.

Het digitaal systeem vervangt de functie van de rol. ${ }^{71}$ Met het verdwijnen van de rol zal ook de functie van rolraadsheer verdwijnen. De behoefte aan het nemen van enkelvoudige beslissingen die het procesverloop betreffen, zal evenwel blijven bestaan. In dat verband is (of zal) bij de hoven de regieraadsheer (worden) geïntroduceerd. Die vervult in wezen de rol die voorheen door de rolraadsheer werd vervuld. Met het handhaven van art. 344 is dit mogelijk gebleven. Door thans uitdrukkelijk te spreken over 'door een enkelvoudige kamer in behandeling genomen' heeft de wetgever willen benadrukken dat de

70. Kamerstukken II 2014/15, 34138, 3, p. 29.

71. Kamerstukken II 2014/15, 34059, 3, p. 8 en 29-31. 
bepaling vooral betrekking heeft op de voorbereidende activiteiten die plaatsvinden bij de binnenkomst van een zaak en niet op de inhoudelijke behandeling daarvan. De inhoudelijke behandeling en beslissing moeten overeenkomstig art. 16 lid 1 in beginsel door de meervoudige kamer plaatsvinden. De wetgever heeft - wat mij betreft: gelukkig ${ }^{72}$ - van de gelegenheid geen gebruik gemaakt om het op ruimere schaal mogelijk te maken dat in hoger beroep ook enkelvoudig wordt beslist (zie voorstel van wet tot wijziging van het Wetboek van Burgerlijke Rechtsvordering in verband met de enkelvoudige behandeling van het hoger beroep in kantonzaken - 33316). ${ }^{73}$

Uiterlijk op het moment dat - ambtshalve of op verzoek van partijen - een mondelinge behandeling zoals bedoeld in art. 30j lid 6 wordt gehouden of uitspraak zal worden gedaan, moet de zaak daarom in handen worden gesteld van een meervoudige kamer. De (meestal enkelvoudige) comparitie na aanbrengen geldt niet als een mondelinge behandeling zoals bedoeld in art. 30j lid 6. ${ }^{74}$ Die kan dus, zonder dat er een meervoudige kamer aan te pas komt, enkelvoudig plaatsvinden, hoewel de praktijk is dat ook die zitting bij een meervoudig gewezen arrest wordt bepaald waarbij een raadsheer-commissaris wordt aangewezen ten overstaan van wie de mondelinge behandeling zal plaatsvinden. Ook de mondelinge behandeling die later in de procedure plaatsvindt, kan overigens nog steeds ten overstaan van een enkelvoudige kamer plaatsvinden. Het ongewijzigd gebleven art. 16 biedt immers de mogelijkheid dat de meervoudige kamer die de zaak behandelt, bepaalt dat de behandeling geheel of gedeeltelijk zal geschieden door een zo veel als mogelijk uit haar midden aangewezen rechter-commissaris. Daarmee blijft ook een enkelvoudige mondelinge behandeling na stukkenwisseling mogelijk. Overigens is de verwijzing in art. 344 naar art. 30j lid 6 een wonderlijke. Ingevolge art. 30j lid 6 kan de rechter met instemming of op verlangen van partijen de mondelinge behandeling achterwege laten en uitspraak doen en in kantonzaken bepalen dat de mondelinge behandeling achterwege blijft indien geen van partijen, nadat zij zijn gewezen op hun recht te worden gehoord, binnen een door hem gestelde redelijke termijn heeft verklaard dat zij gebruik wil maken van dit recht. Deze bepaling is dus geschreven voor de situatie in eerste aanleg waar het houden van een mondelinge behandeling in elke zaak het wettelijke uitgangspunt is. Van dat uitgangspunt is nu juist in hoger beroep afgeweken (zie par. 5.2). Volgens de memorie van toelichting is de specifieke verwijzing naar art. 30j lid 6 erdoor ingegeven dat daarmee het onderscheid met de comparitie na aanbrengen wordt benadrukt. Art. 30j lid 6 zou het meest duidelijke verschil tussen een com-

72. Zie hierover F.J.P. Lock, Unusrechtspraak in kantonzaken in het civiele hoger beroep, TvPP 2013, afl. 2, p. 30-37.

73. Zie ook Agenda voor de appelrechtspraak 2020, p. 14, aanbeveling 1: 'In het belang van de legitimiteit van het hoger beroep wordt an de meervoudige zaaksbehandeling niet getornd', en J.J. Dammingh, De (on)wenselijkheid van unusrechtspraak in het civielrechtelijke hoger beroep, in: P.H.P.H.M.C. van Kempen e.a. (red.), Hoger beroep, renovatie en innovatie, Deventer: Kluwer 2014, p. 173-184.

74. Zie ook Kamerstukken II 2014/15, 34138, 3, p. 29 en 30. paritie na aanbrengen en een mondelinge behandeling voor een meervoudige kamer zijn omdat een comparitie na aanbrengen niet met instemming of op verlangen van partijen achterwege gelaten kan worden. ${ }^{75} \mathrm{Ik}$ zie evenwel niet in waarom een comparitie na aanbrengen niet op verlangen van partijen achterwege gelaten zou kunnen worden. Het is zelfs praktijk bij sommige hoven om met zoveel woorden in het comparitiearrest waarbij een comparitie na aanbrengen wordt bepaald, op te nemen dat partijen (eenstemmig) van de zitting kunnen afzien. Maar ook indien dat niet is bepaald, staat het mijns inziens de rechter vrij de zitting geen doorgang te laten vinden indien partijen hem laten weten daaraan geen behoefte te hebben.

\subsection{De mondelinge behandeling}

De mondelinge behandeling geldt als een van de paradepaardjes van de wet. In de wetsgeschiedenis wordt de mondelinge behandeling het hart en een van de belangrijkste pijlers van de nieuwe basisprocedure genoemd. ${ }^{76}$ In art. $30 \mathrm{k}$, dat de mondelinge behandeling regelt, is bepaald dat de rechter tijdens de mondelinge behandeling partijen in de gelegenheid stelt om hun standpunten mondeling toe te lichten (lid 1), inlichtingen kan verzamelen (lid 1 onder a), partijen de gelegenheid kan bieden om hun stellingen nader te onderbouwen (lid 1 onder b), een schikking kan beproeven (lid 1 onder c), met partijen kan overleggen over het verdere verloop van de procedure (lid 1 onder d) en aanwijzingen kan geven of proceshandelingen kan bevelen die hij geraden acht, voor zover hij dit in overeenstemming acht met de eisen van een goede procesorde (lid 1 onder e). Hij kan ook getuigen en deskundigen horen (lid 2).

Het recht op pleidooi (het huidige art. $134 \mathrm{Rv}$ ) als zodanig komt te vervallen, aangezien partijen tijdens de mondelinge behandeling hun standpunten mondeling kunnen toelichten. De Adviescommissie burgerlijk procesrecht merkte hierover op:

'Een interactieve en dynamische mondelinge behandeling verdient verreweg de voorkeur boven een statisch pleidooi. Een mondelinge behandeling biedt ruimte aan de rechter om opheldering te krijgen over bepaalde feitelijke of juridische aspecten van het geschil, en aan partijen om hun stellingen toe te lichten en te verduidelijken, naar elkaars standpunten te luisteren en daarop te reageren. In een mondelinge behandeling kunnen ook de achterliggende belangen aan de orde komen en kan de rechter conflictoplossing in brede zin faciliteren, waarbij schikkingsmogelijkheden evenzeer kunnen worden besproken als een verwijzing naar mediation of voeging met andere lopende zaken over hetzelfde conflict. ${ }^{, 77}$

\footnotetext{
75. Kamerstukken II 2014/15, 34138, 3, p. 30.

76. Kamerstukken II 2014/15, 34059, 3, p. 70 en Kamerstukken II 2014/15, 34138, 3, p. 9.

77. Kamerstukken II 2014/15, 34059, 3, p. 71.
} 
Dit geldt evenzeer voor het hoger beroep. ${ }^{78}$

Anders dan in eerste aanleg is een mondelinge behandeling in hoger beroep facultatief. Waar de basisprocedure ook als uitgangspunt dient voor de procedure in hoger beroep, was het aanvankelijk de bedoeling dat de mondelinge behandeling ook een centrale plaats in de procedure in hoger beroep zou gaan innemen. In het ontwerp van wet zoals dat ter consultatie op internet was geplaatst, was voor het hoger beroep voorzien in dezelfde regeling als voor de procedure in kantonzaken: uitgangspunt is dat een mondelinge behandeling plaatsvindt, tenzij de rechter bepaalt dat deze achterwege blijft en partijen of een van hen, nadat zij zijn gewezen op het recht om ter zitting te worden gehoord, niet binnen een door de rechter gestelde redelijke termijn hebben verklaard dat zij van dat recht gebruik willen maken. Ook de Nederlandse Orde van Advocaten pleitte ervoor te bepalen dat in elke zaak in hoger beroep een mondelinge behandeling wordt gehouden, met de mogelijkheid voor partijen om daarvan eenstemmig af te zien. ${ }^{79}$ Dit uitgangspunt (mondelinge behandeling, tenzij) is, kennelijk onder druk van de hoven tijdens de zogenoemde expertbijeenkomsten, ${ }^{80}$ evenwel weer verlaten. De verplichting (bedoeld zal zijn: het uitgangspunt) om een mondelinge behandeling te houden in elke procedure werd niet opportuun geacht. Daarvoor in de plaats geldt nu ingevolge art. 354 dat een mondelinge behandeling plaatsvindt indien de rechter daartoe aanleiding ziet of indien een van partijen, nadat zij zijn gewezen op hun recht te worden gehoord, binnen een door de rechter gestelde redelijke termijn heeft verklaard dat zij gebruik wil maken van dit recht (mondelinge behandeling, indien). Hiermee heeft de wetgever beoogd de hoven niet te dwingen de bestaande praktijk te wijzigen. De minister heeft er alle vertrouwen in dat de rechtspraak zorgvuldig zal omgaan met de mogelijkheid om van een mondelinge behandeling af te zien. ${ }^{81}$ Gelet op de door alle hoven op grote schaal toegepaste comparitie na aanbrengen en de toenemende bewustwording van de regierol van de rechter, van de mogelijkheden die een mondelinge behandeling biedt om meer begrip van de zaak te krijgen en partijen tot een minnelijke regeling te bewegen en van het belang van een mondelinge behandeling voor partijen (hun

78. Zie in deze zin ook G. Makkink, Toegang tot hoger beroep in civiele zaken, in: A. Hol \& J. Verburg (red.), Innoverende hoven, Den Haag: Boom Juridische uitgevers 2014, p. 189-190: 'Een mondelinge behandeling door een actieve meervoudige kamer draagt in wezenlijke mate bij aan de rechterlijke oordeelsvorming en aan de acceptatie van het rechterlijk oordeel. Deze vorm van toegang tot de rechter voorziet bovendien in de behoefte van veel procespartijen (hun day in court) en dient een centrale plaats in te nemen in de behandeling in hoger beroep. Indien de mondelinge behandeling zodanig wordt ingericht dat partijen in voldoende mate hun standpunt uiteen kunnen zetten, kunnen pleidooien, die in de regel veel minder toegevoegde waarde hebben, achterwege blijven.'

79. Kamerstukken II 2014/15, 34138, 3, p. 21.

80. Kamerstukken II 2014/15, 34138, 3, p. 9.

81. Kamerstukken II 2014/15, 34138, 3, p. 19. 'day in court', ook in hoger beroep), bestaan de hoop ${ }^{82}$ en de verwachting dat onder het nieuwe procesrecht de appelrechter vaker dan voorheen in vorderingsprocedures gebruik zal maken van de mogelijkheid een (al dan niet meervoudige) mondelinge behandeling (comparitie van partijen) te bepalen. ${ }^{83}$ De oproep voor een veelvuldiger en intensiever gebruik van de comparitie na antwoord in de civiele appelprocedure is al vaker gedaan, ${ }^{84}$ en zou ik hier graag herhalen.

In verzoekprocedures vindt in hoger beroep ook nu al bijna altijd een mondelinge behandeling plaats. Het is niet de bedoeling dat het wetsvoorstel in deze praktijk verandering brengt. ${ }^{85}$

Partijen kunnen ook zelf om een mondelinge behandeling verzoeken. $\mathrm{Zij}$ moeten worden gewezen op hun recht daarop en daarbij moet hun een redelijke termijn worden gegund om te verklaren van dat recht gebruik te willen maken. In de praktijk zal dit betekenen dat de rechter na indiening van de laatste memorie van antwoord beoordeelt of de zaak zich leent voor een mondelinge behandeling, en indien dat naar zijn oordeel niet het geval is, partijen een termijn geeft waarbinnen zij zich erover kunnen uitlaten of zij een mondelinge behandeling wensen. De tekst van art. 354 biedt, evenals het vroegere art. 134 (recht op pleidooi), de rechter geen ruimte om een verzoek tot het houden van een mondelinge behandeling te weigeren. Dit vloeit ook voort uit art. 6 van het Europees Verdrag tot bescherming van de rechten van de mens en de fundamentele vrijheden. Waar de Hoge Raad ten aanzien van het pleidooi heeft geoordeeld dat een in hoger beroep gedaan verzoek om te mogen pleiten slechts in uitzonderlijke gevallen mag worden afgewezen, ${ }^{86}$ zal dit evenzeer gelden voor een in hoger beroep gedaan verzoek om een mondelinge behandeling in de zin van art. 354 . Dit betekent dat een verzoek om een monde-

82. Ik deel deze hoop met Klaassen, zie Klaassen 2016, p. 80; zie over het belang en de meerwaarde van de mondelinge behandeling in hoger beroep ook W.L. Valk, De mondelinge behandeling in het civiele hoger beroep, in: P.H.P.H.M.C. van Kempen e.a. (red.), Hoger beroep, renovatie en innovatie, Deventer: Kluwer 2014, p. 161-172.

83. In hof Arnhem-Leeuwarden wordt al, vooruitlopend op KEI, in elke zaak na de laatste memorie van antwoord beoordeeld of de zaak zich leent voor een (veelal meervoudige) mondelinge behandeling. De eerste voorzichtige ervaringen tonen aan dat in een aanzienlijk deel van die geselecteerde zaken (circa 20 à 25 procent) partijen op deze zitting alsnog een minnelijke regeling bereiken, terwijl in het grootste deel van de zaken waarin partijen daarin niet slagen, de raadsheren beter geïnformeerd en ook sneller kunnen beslissen. Voor deze gegevens dank ik L.D.E. Vink, die het effect van de in de periode oktober 2015 tot juni 2016 bij het hof Arnhem-Leeuwarden gehouden comparities na memorie van antwoord heeft onderzocht (Loes Vink is student HBO-recht aan de Hogeschool Arnhem-Nijmegen en stagiaire en buitengriffier bij het hof Arnhem-Leeuwarden, locatie Arnhem).

84. Zie o.a. T. Tanja-van den Broek \& B. van Lierop, Pleidooi voor de comparitie na antwoord in hoger beroep, Trema 2008, p. 129-130; R.A. Dozy \& W.L. Valk, Innovatief instrueren in hoger beroep, Trema 2010, p. 466; Makkink 2014, p. 189-190.

85. Kamerstukken II $2014 / 15,34138,3$, p. 9.

86. Zie o.a. HR 2 december 2011, ECLI:NL:HR:2011:BT7596, JBPr 2012/23 m.nt. Vos, NJ 2011/575; HR 27 januari 2012, ECLI:NL:HR: 2012:BU7254, JBPr 2012/27, NJ 2012/77; HR 27 januari 2012, ECLI:NL:HR:2012:BU8513, JBPr 2012/26, NJ 2012/76. 
linge behandeling alleen zal mogen worden afgewezen indien van de zijde van de wederpartij tegen toewijzing van het verzoek klemmende redenen worden aangevoerd of indien toewijzing van het verzoek strijdig zou zijn met de eisen van een goede procesorde. Als de rechter oordeelt dat een van deze uitzonderingen zich voordoet, dan zal hij de redenen voor afwijzing van het verzoek uitdrukkelijk moeten vermelden en zijn beslissing daaromtrent deugdelijk moeten motiveren. ${ }^{87}$ In de memorie van toelichting is nog uitdrukkelijk overwogen dat het feit dat een comparitie na aanbrengen heeft plaatsgevonden, niet maakt dat er geen plaats meer is voor een (nieuwe) mondelinge behandeling als bedoeld in art. $30 \mathrm{j}$ lid 6 . Een comparitie na aanbrengen vindt immers veelal plaats voordat de eiser zijn gronden en de verweerder zijn verweer heeft ingediend. Indien een comparitie na aanbrengen heeft plaatsgevonden en een partij vervolgens verzoekt om een mondelinge behandeling, kan dit verzoek niet worden afgewezen op grond van het enkele feit dat al een comparitie na aanbrengen heeft plaatsgevonden. De gronden en het verweer kunnen aanleiding geven voor een (nieuwe) mondelinge behandeling.

Op de inrichting en het verloop van de mondelinge behandeling zijn de bepalingen van de uniforme basisprocedure van overeenkomstige toepassing (art. 353 lid 2). Dit betekent dus ook dat ter gelegenheid van de mondelinge behandeling getuigen kunnen worden gehoord (art. 30k lid 2).

\subsection{Mondeling uitspraak}

In art. 30p is bepaald dat de rechter mondeling uitspraak kan doen. De bedoeling daarvan is dat een doelmatige procesvoering in bepaalde gevallen kan worden bevorderd, met tijdwinst voor partijen en de rechter tot gevolg. ${ }^{88}$ Een mondelinge uitspraak moet worden vastgelegd in het proces-verbaal (art. 30p lid 3) en moet het dictum en de gronden bevatten (art. 30p lid 2 ). Dit impliceert dat het gaat om een gemotiveerde beslissing.

Deze bepaling is ook in hoger beroep van toepassing, zij het dat art. 357 lid 2 de mogelijkheid wel beperkt tot een tussenarrest of een eindarrest in kort geding. Het eindarrest in een bodemzaak in een vorderingsprocedure mag dus niet (uitsluitend) mondeling worden gedaan. Een mondelinge uitspraak ligt volgens de wetgever in deze categorie niet voor de hand, gezien het vaak gecompliceerde karakter van de zaak, de motivering die gerelateerd moet zijn aan de gronden en daarom uitgebreider is dan in eerste aanleg, en de omstandigheid dat een meervoudige kamer de zaak behandelt. De mogelijkheid om in hoger beroep ter zitting mondeling uitspraak te doen is dus beperkt tot tussen- en eindbeschikkingen in verzoekprocedures, tot tussenarresten in vorderingszaken en tot uitspraken in kort geding. Blijkens de memorie van toelichting moet evenwel ook in die gevallen met de mogelijkheid om ter zitting mondeling uitspraak te doen prudent worden omgesprongen.

87. Zie hierover ook F.J.P. Lock, Hoger beroep, TCR 2013, afl. 1, p. 33 en 34 en C.J.M. Klaassen, Het recht op pleidooi, mede in het licht en zicht van KEI: een terug- en vooruitblik, AA 2016, p. 185-190.

88. Kamerstukken II 2014/15, 34138, 3, p. 10.
Voorkomen moet worden dat de toetsing van (een proces-verbaal van) een mondelinge uitspraak in cassatie niet goed mogelijk is. ${ }^{89}$

Aandacht verdient nog dat de rechter ten overstaan van wie de mondelinge behandeling heeft plaatsgevonden in beginsel ook de rechter moet zijn die uitspraak doet. ${ }^{90}$ De Hoge Raad heeft geoordeeld dat: '[e]en rechterlijke beslissing die mede wordt genomen op de grondslag van een voorafgaande mondelinge behandeling (...), behoudens bijzondere omstandigheden, [behoort] te worden gegeven door de rechter(s) ten overstaan van wie die mondelinge behandeling heeft plaatsgevonden (...)'. Voor hoger beroep betekent dit dat de raadsheer-commissaris (in geval van een enkelvoudige mondelinge behandeling) of de meervoudige kamer ten overstaan waarvan de mondelinge behandeling heeft plaatsgevonden ook het daaropvolgende arrest zal moeten (mee)wijzen. Voor toepassing van deze regel bestaat geen grond ingeval sprake is van een wisseling van een van de rechters na een op een eerdere mondelinge behandeling gevolgde uitspraak, en aan de verdere beoordeling van het geschil een tweede mondelinge behandeling voorafgaat. In die tweede behandeling kunnen partijen immers desgewenst de geschilpunten waarop in de vorige uitspraak nog niet was beslist, opnieuw of nader aan de orde stellen ten overstaan van de rechters die over die geschilpunten zullen beslissen. ${ }^{91}$ Of dit ook geldt voor de raadsheer(-commissaris) ten overstaan van wie de comparitie na aanbrengen heeft plaatsgevonden, was enige tijd onduidelijk, maar ook daarin heeft de Hoge Raad inmiddels de weg gewezen: de regel geldt in dat geval niet. ${ }^{92}$

\subsection{Regie}

In de wetsgeschiedenis wordt herhaaldelijk gewezen op het belang van het voeren van regie door de rechter. ${ }^{93}$ Dit geldt ook in hoger beroep. Het is aan de rechter, aldus de memorie van toelichting, om maatwerk te bieden. De appelrechter kan op verschillende momenten en op verschillende manieren regie voeren. Dit kan het regelen van termijnen betreffen, maar de rechter kan ook regie voeren door een comparitie na aanbrengen te houden of door te beslissen over het houden van een mondelinge behandeling en over de invulling daarvan. ${ }^{94}$ De wetswijzigingen bieden de rechter hiervoor niet heel veel meer handvatten dan die hij reeds onder het huidige pro-

89. Kamerstukken II 2014/15, 34138, 3, p. 10.

90. HR 31 oktober 2014, ECLI:NL:HR:2014:3076, NJ 2015/181 m.nt Asser. Zie hierover uitgebreid J.P. de Haan \& M.R.T. Pauwels, Personele eenheid van behandeling en uitspraak. Over HR 31 oktober 2014 (ECLI:NL:HR:2014:3076), TCR 2016, afl. 1, p. 1-7 en Klaassen 2016.

91. HR 15 april 2016, ECLI:NL:HR:2016:662, r.o. 3.4.

92. HR 15 april 2016, ECLI:NL:HR:2016:662, r.o. 3.9.

93. Zie over het voeren van regie door de rechter en het hanteren van verschillende begrippen 'regie' in het kader van KEI: J.D.A. den Tonkelaar, De regisserende zaaksrechter: de regierol van de rechter volgens KEI, TCR 2015, afl. 4, p. 105-113, alsmede P.W.A. van Geloven, Het thema 'Regiebureau' in de gerechten, Trema 2016, p. 162-169 en D.T. Boks \& J.D.A. den Tonkelaar, Regie door de zaaksrechter, Trema 2016, p. $170-179$.

94. Kamerstukken II 2014/15, 34138, 3, p. 12. 
cesrecht heeft. Wel zal de focus van de appelrechter wellicht mede onder invloed van KEI en de door de wetgever geuite wens dat de rechter meer regie voert, (langzaam) worden verlegd. Waar de appelrechter in vorderingsprocedures van oudsher in procesrechtelijk opzicht een lijdelijke houding aannam en in de grote meerderheid van de zaken louter recht deed op de stukken, lijkt er een tendens naar een actievere rol van de appelrechter, ${ }^{95}$ die in steeds meer zaken op zoek is naar het rechtstreekse contact met partijen door het houden van een zitting. ${ }^{96}$ Die tendens is al eerder ingezet met de inmiddels bij alle hoven in zwang geraakte comparitie na aanbrengen en het zal mij niet verbazen als die tendens zich verder voortzet. Ik noemde al eerder dat bij het gerechtshof Arnhem-Leeuwarden in alle zaken wordt beoordeeld of de zaak zich leent voor een mondelinge behandeling na stukkenwisseling. Er wordt dus niet meer 'zomaar' recht gedaan op de stukken en er wordt niet gewacht of partijen zelf om pleidooi verzoeken. Het hof neemt de regie zelf in handen.

Deze meer actieve rol van de appelrechter kan overigens gemakkelijk botsen met de procesrechtelijke kaders die hem worden opgelegd door het grievenstelsel en de tweeconclusieregel. Waar de appelrechter meer de regie voert over de wijze waarop de procedure verloopt en de mondelinge behandeling wordt ingericht, doet hij dat met een doel. Dat doel zal zijn een goed en efficiënt verloop van de procedure, maar ook een kwalitatief goede uitspraak. ${ }^{97}$ En bij een kwalitatief goede uitspraak stellen de meeste rechters zich niet alleen een in een ambachtelijk opzicht goede uitspraak voor (is de uitspraak tijdig gedaan, is de beslissing goed en duidelijk gemotiveerd, is er geen bewijsaanbod over het hoofd gezien, zijn alle verweren behandeld, enzovoort), maar vooral ook een uitspraak die zo veel mogelijk recht doet aan de daadwerkelijke materieelrechtelijke rechtspositie van partijen. ${ }^{98}$ Dat vereist soms een ingrijpen in het partijdebat. Over de grenzen waartegen de appelrechter dan aanloopt, schreef $\mathrm{ik}$ - aan de hand van twee arresten waarin het hof naar het oordeel van de Hoge Raad te veel had ingegrepen in het partijdebat - reeds eerder. ${ }^{99}$ Asser heeft

95. In de literatuur wordt het uitgangspunt van partijautonomie en lijdelijkheid van de civiele rechter steeds vaker genuanceerd of zelfs als achterhaald beschouwd, zie bijv. Snijders, Klaassen \& Meijer 2011, p. 50-51, Stein/Rueb, Compendium van het burgerlijk procesrecht, Deventer: Kluwer 2013, p. 37, M.J.A.M. Ashmann, De weg naar het civiele vonnis, Den Haag: Boom Juridische uitgevers 2011, p. 74-75 en R.H. de Bock, Tussen waarheid en onzekerheid: over het vaststellen van feiten in de civiele procedure (diss. Tilburg), Deventer: Kluwer 2011, p. 86 e.v.

96. Deze tendens werd bijv. ook al gesignaleerd door G. Pesselse, Renovatie en innovatie van het hoger beroep in drie rechtsgebieden. Appellen en peren?, Trema 2014, p. 224, onder verwijzing naar Valk 2014, W.D.H. Asser, H.A. Groen \& J.B.M. Vranken, Uitgebalanceerd: eindrapport fundamentele herbezinning Nederlands burgerlijk procesrecht, Den Haag: Boom Juridische uitgevers 2006, p. 45-60 en G.C.C. Lewin, Mag het bandje wat minder strak, in: Hoger beroep (preadviezen Nederlandse Vereniging voor Procesrecht), Den Haag: Boom Juridische uitgevers 2011, p. 9-16.

97. Vgl. Kamerstukken II 2014/15, 34059, 3, p. 1.

98. Zie G.C.C. Lewin, Het burgerlijk procesrecht is de pathologie van het recht (oratie Amsterdam UvA), Deventer: Kluwer 2013, daarin bijgevallen door o.a. Valk 2014, p. 164.

99. Lock 2013, p. 29-31. ook gewezen op de rode lichten die in dit verband de appelrechter een halt toeroepen. ${ }^{100} \mathrm{Ik}$ deel de conclusie van Asser dat ook de appelrechter soms de ruimte (Asser spreekt zelfs over de plicht) moet hebben om bij te sturen als partijen vanuit de optiek van een juiste rechtstoepassing en een rechtvaardige beslissing in het geschil niet de goede keuzes hebben gemaakt. Die ruimte kan hij nodig hebben doordat partijen vergeten zijn tegen een onjuist rechtsoordeel van de eerste rechter een grief te richten, ${ }^{101}$ of doordat zij een verweer (bijvoorbeeld een beroep op een uit dwingend recht voortvloeiende vernietigingsgrond) niet hebben gevoerd. De rechter die waakt over de rechtstoepassing op de feiten zal dan de regie moeten kunnen nemen en corrigerend in het partijdebat moeten kunnen optreden, uiteraard met respect voor de partijautonomie (als de partij die het aangaat het ingrijpen toch niet wenst, zal de rechter daarvan moeten afzien) en immer met inachtneming van het beginsel van hoor en wederhoor. Deze vorm van regievoering gaat verder dan alleen het voeren van regie op de procedure. ${ }^{102}$

\section{Afsluiting}

De belangrijkste uitgangspunten voor de procedure in hoger beroep, zoals die ten aanzien van de devolutieve werking en het grievenstelsel, zijn door de KEI-wetgever ongemoeid gelaten. Hoewel de toelichting de mond vol heeft van de mondelinge behandeling en de versterking van de regiefunctie, geldt daarvoor dat de wetswijziging de appelrechter nauwelijks nieuwe handvatten biedt. Ook van een uniformering van de vorderings- en verzoekprocedures is weinig terechtgekomen. $\mathrm{Er}$ is in naam weliswaar sprake van eenzelfde procesinleidend stuk, maar de procesinleiding behoeft in de verschillende procedures niet aan dezelfde eisen te voldoen en ook de wijze waarop de procesinleiding wordt bekendgemaakt aan de andere procespartijen is in beide procedures verschillend.

Naast de digitalisering van de procedure, zijn de opvallendste wetswijzigingen dat de procesinleiding in vorderingsprocedures ook op informele wijze aan de wederpartij kan worden bezorgd, dat na de inwerkingtreding van het digitaal procederen voor zowel de vorderings- als de verzoekprocedure met één procesinleiding hoger beroep kan worden ingesteld van een uitspraak, waarbij zowel is beslist op een verzoek als op een vordering, dat de termijnen voor het indienen van processtukken en het doen van uitspraak in de wet zijn vastgelegd, dat het recht op pleidooi als zodanig is vervallen (maar nog steeds wel een recht op een mondelinge behandeling bestaat) en dat

100. W.D.H. Asser, Ambtshalve toepassing van rechtsgronden door de Nederlandse rechter, in: Preadviezen 2015 voor de Vereniging voor de vergelijkende studie van het recht van België en Nederland, Den Haag: Boom Juridische uitgevers 2015, p. 340-345.

101. Zie over de 'enge leer' en de 'ruime leer' ten aanzien van de vraag of de rechter aan een dergelijk onjuist rechtsoordeel gebonden is, o.a. de noot van Lewin onder HR 17 april 2015, ECLI:NL:HR:2015:1063, JBPr 2015/49, met verwijzing naar relevante literatuur.

102. Regeringscommissaris Hammerstein lijkt de regierol alleen te betrekken op een goede voortgang en efficiënte inrichting van de procedure, Kamerstukken II 2014/15, 34059, 13. 
uitdrukkelijk is voorzien in de mogelijkheid van het doen van mondelinge uitspraak. Verder zijn vertrouwde begrippen vervangen door nieuw jargon. Maar spectaculair zijn die wijzigingen niet te noemen. Van een vereenvoudiging van de civiele procedure en een stroomlijning van het hoger beroep, zoals het regeerakkoord van het kabinet-Rutte II nog ambitieus aankondigde, ${ }^{103}$ kan nauwelijks worden gesproken. Dat is ook wel verklaarbaar als we bedenken dat de ambitie van de wetgever uiteindelijk niet veel verder reikte dan de civiele procedure klaar te maken voor de beoogde digitalisering daarvan.

De belangrijkste verandering lijkt dan ook niet zozeer te kunnen worden gevonden in de wetstechnische wijzigingen die zijn doorgevoerd. Belangrijker is misschien wel de wens van de wetgever dat de rechter, ook de appelrechter, zich actiever opstelt, meer de regie neemt en het belang van een mondelinge behandeling (ook in vorderingszaken) steeds meer gaat inzien. Door zowel de raadsheren, die van oudsher gewend zijn zich afwachtend op te stellen en in de meeste zaken louter recht te doen op de stukken, als de advocaten, die gewend zijn dat de regie over de wijze waarop het debat verloopt vooral in de handen van partijen ligt, zal dit als een cultuuromslag kunnen worden ervaren en zal de gewenste mentaliteitsverandering nog het nodige van hen vragen. Het is evenwel een ontwikkeling die wat mij betreft, net als de digitalisering van de rechtspraak, past in de tijdgeest.

103. Bruggen slaan, regeerakkoord VVD-PvdA, 29 oktober 2012, p. 27: 'Het civiele proces wordt vergaand vereenvoudigd en gedigitaliseerd. Het onderscheid tussen verzoekschrift en dagvaarding kan vervallen. Hoger beroep wordt gestroomlijnd.' 